Reactor Technology (TID-4500, 43rd Ed.) $A E C$ Research and Development Report

ARGONNE NATIONAL LABORATORY

9700 South Cass Avenue

Argonne, Illinois 60440

NEUTRON-FLUX STUDIES IN THE EBWR DURING POWER OPERATION

\author{
by \\ W. G. Knapp \\ Reactor Physics Division
}

March 1965
Operated by The University of Chicago under
Contract W-31-109-eng-38 with the
U.S. Atomic Energy Commission




\section{DISCLAIMER}

This report was prepared as an account of work sponsored by an agency of the United States Government. Neither the United States Government nor any agency Thereof, nor any of their employees, makes any warranty, express or implied, or assumes any legal liability or responsibility for the accuracy, completeness, or usefulness of any information, apparatus, product, or process disclosed, or represents that its use would not infringe privately owned rights. Reference herein to any specific commercial product, process, or service by trade name, trademark, manufacturer, or otherwise does not necessarily constitute or imply its endorsement, recommendation, or favoring by the United States Government or any agency thereof. The views and opinions of authors expressed herein do not necessarily state or reflect those of the United States Government or any agency thereof. 


\section{DISCLAIMER}

Portions of this document may be illegible in electronic image products. Images are produced from the best available original document. 
TABLE OF CONTENTS

Page

ABSTRACI ........................... 7

1. INTRODUCTION. ...................... 7

1.1 Objectives........................ 7

1.2 Background ........................... 8

2. DETERMINATION OF NEUTRON-FLUX DISTRIBUTION

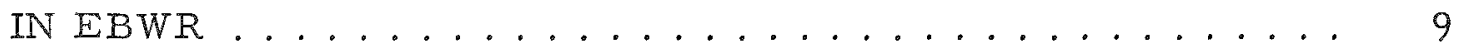

2.1 Method for Foil Irradiation and Analysis ........... 9

2.2 Calculation of Neutron-flux Levels from Foil Data...... 11

3. DISCUSSION OF RESUITS .................... 12

3.1 Effect of Reactor Power on Neutron-flux Distribution

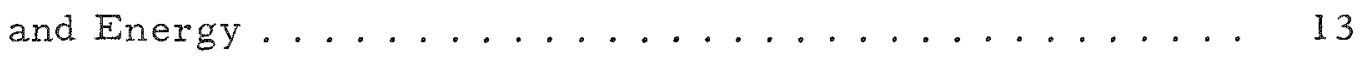

3.1 .1 In Absence of Soluble Poison ............. 13

3.1 .2 In Presence of Soluble Poison ............ 13

3.2 Effect of Soluble-poison Concentration on Neutron-flux

Distribution and Energy................ 18

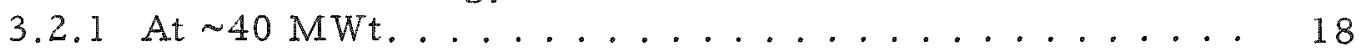

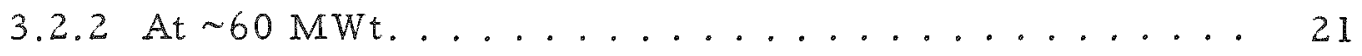

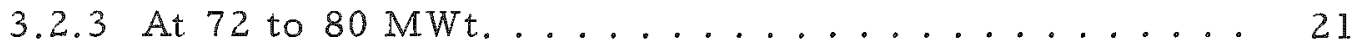

4. PROPOSED FUTURE STUDIES IN EBWR OR SIMILAR POWER

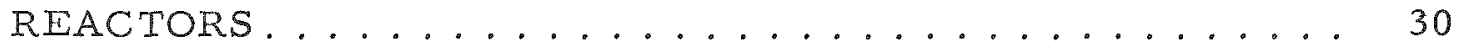

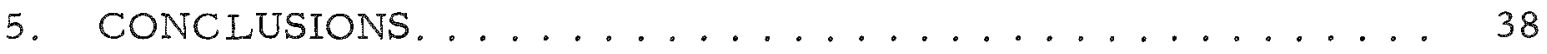

ACKNOWLEDGMENTS ........................... 39

REFERENCES ............................. 40 


\section{LIST OF FIGURES}

No.

Title

$\underline{\text { Page }}$

1. Sample Assembly. (A) Partially Assembled, Bare Foil; (B) Partially Assembled, Cadmium-covered Foil; (C) Completed

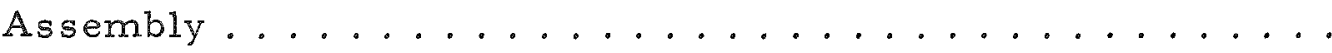

2. Foil-irradiation Locations Used for Data Presented in Figs. 4-24, Inclusive.....................

3. Schematic Diagram of Irradiation-analysis Procedure Used in Study of EBWR Neutron-flux Distribution .............

4. Thermal-neutron-flux Isogram Plot for Reactor Power of $21 \mathrm{MWt}$, Soluble-poison Concentration of 25 ppm as Boric Acid.

5. Resonance-neutron-flux Isogram Plot for Reactor Power of $21 \mathrm{MWt}$, Soluble-poison Concentration of 25 ppm as Boric Acid.

6. Thermal-neutron-flux Isogram Plot for Reactor Power of 41.2 MWt, Soluble-poison Concentration of 25 ppm as Boric Acid.

7. Resonance-neutron-flux Isogram Plot for Reactor Power of 41.2 MWt, Soluble-poison Concentration of 25 ppm as Boric

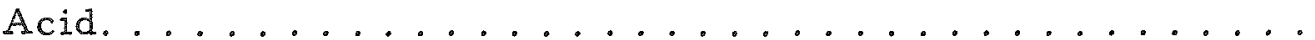

8. Thermal-neutron-flux Isogram Plot for Reactor Power of $42 \mathrm{MWt}$, Soluble-poison Concentration of 1200 ppm as Boric

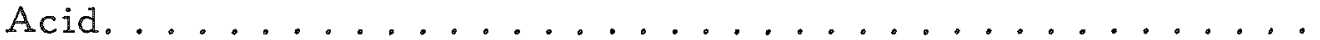

9. Resonance-neutron-flux Isogram Plot for Reactor Power of $42 \mathrm{MWt}$, Soluble-poison Concentration of 1200 ppm as Boric Acid. .......................

10. Thermal-neutron-flux Isogram Plot for Reactor Power of $62 \mathrm{MWt}$, Soluble-poison Concentration of $25 \mathrm{ppm}$ as Boric Acid. . . . . . . . . . . . . . . . . . . .

11. Resonance-neutron-flux Isogram Plot for Reactor Power of $62 \mathrm{MWt}$, Soluble-poison Concentration of 25 ppm as Boric

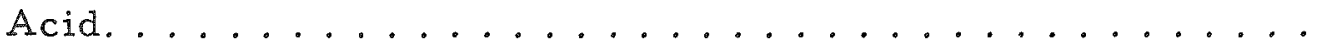

12. Thermal-neutron-flux Isogram Plot for Reactor Power of $58 \mathrm{MWt}$, Soluble-poison Concentration of $120 \mathrm{ppm}$ as Boric

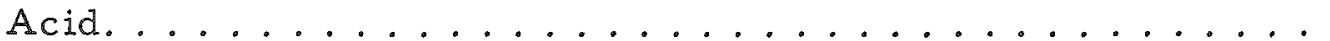

13. Resonance-neutron-flux Isogram Plot for Reactor Power of $58 \mathrm{MWt}$, Soluble-poison Concentration of 120 ppm as Boric Acid. 


\section{LIST OF FIGURES}

No.

$\underline{\text { Title }}$

$\underline{\text { Page }}$

14. Neutron-flux Isogram Plot Determined from Bare Cobalt Foil Activation Only, for Reactor Power of $21 \mathrm{MWt}$, Soluble-poison Concentration of 25 ppm as Boric Acid. . . . . . . . . .

15. Neutron-flux Isogram Plot Determined from Bare Cobalt Foil Activation Only, for Reactor Power of $41.2 \mathrm{MWt}$, Solublepoison Concentration of 25 ppm as Boric Acid..........

16. Neutron-flux Isogram Plot Determined from Bare Cobalt Foil Activation Only for Reactor Power of $40 \mathrm{MWt}$, Soluble-poison Concentration of $900 \mathrm{ppm}$ as Boric Acid............

17. Neutron-flux Isogram Plot Determined from Bare Cobalt Foil Activation Only, for Reactor Power of $42 \mathrm{MWt}$, Soluble-poison Concentration of $1200 \mathrm{ppm}$ as Boric Acid . . . . . . . . .

18. Neutron-flux Isogram Plot Determined from Bare Cobalt Foil Activation Only, for Reactor Power of $62 \mathrm{MWt}$, Soluble-poison Concentration of 25 ppm as Boric Acid. . . . . . . . . .

19. Neutron-flux Isogram Plot Determined from Bare Cobalt Foil Activation Only, for Reactor Power of $58 \mathrm{MWt}$, Soluble-poison Concentration of 120 ppm as Boric Acid............

20. Neutron-flux Isogram Plot Determined from Bare Cobalt Foil Activation Only, for Reactor Power of $60 \mathrm{MWt}$, Soluble-poison Concentration of 925 ppm as Boric Acid............

21. Neutron-flux Isogram Plot Determined from Bare Cobalt Foil Activation Only, for Reactor Power of 78-80 MWt, Solublepoison Concentration of 25 ppm as Boric Acid .........

22. Neutron-flux Isogram Plot Determined from Bare Cobalt Foil Activation Only, for Reactor Power of $72 \mathrm{MWt}$, Soluble-poison

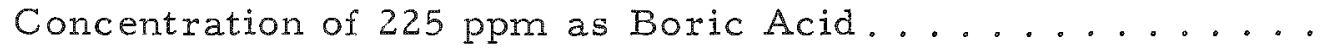

23. Neutron-flux Isogram Plot Determined from Bare Cobalt Foil Activation Only, for Reactor Power of $75 \mathrm{MWt}$, Soluble-poison

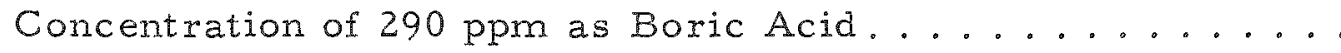

24. Neutron-flux Isogram Plot Determined from Bare Cobalt Foil Activation Only, for Reactor Power of $80 \mathrm{MWt}$, Soluble-poison Concentration of 540 ppm as Boric Acid........... 


\section{LIST OF TABLES}

No.

Title

Page

I. Summary of Irradiation Conditions for Data in Figs. 4-24,

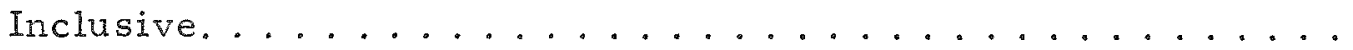

II. Radioactivants to be Used in Neutron-flux Studies in the Plutonium Recycle Experiment............... 


\title{
NEUTRON-FLUX STUDIES IN THE EBWR DURING POWER OPERATION
}

by

W. G. Knapp

\begin{abstract}
The neutron-flux distribution in the Experimental Boiling Water Reactor (EBWR) core during power operation has been studied through the use of activation foil detectors. The method described in ANL-7011 was used for irradiation and analysis of the detectors. From data obtained with bare and cadmium-covered, cobalt-aluminum alloy foils, neutron-flux isogram plots have been prepared. The effects of reactor power changes, soluble-poison concentration, and control rod positions on the the rmal and resonance neutronflux distribution are shown.
\end{abstract}

\section{INTRODUCTION}

The neutron-flux distribution in the EBWR core during power operation has been studied using a foil activation technique reported. (1) By this method, foils were introduced into specific core locations for short-term irradiation without affecting the normal reactor power operation. Bare and cadmium-covered cobalt foils were irradiated with selected reactor operating parameters. The effect of varying power, soluble poison concentrations, and control rod positions on the neutron flux distribution was determined. The data accumulated during the study and presented in this report will be of interest to reactor physicists and engineers concerned with neutronics of boiling-water reactors.

\subsection{Objectives}

The long-range objectives of the study were to characterize, as well as possible, both the neutron-flux distribution and the energy spectrum in the operating EBWR as a function of several operating parameters, namely power level, soluble-poison concentration, control rod positions, and fuelloading configuration These objectives were only partially realized during the time arailable for reactor experiments before the shutdown of the EBWR in December 1962. A firm ground work has been laid, however, for extension of the studies and a fuller realization of the objectives in future EBWR Plutonium Recycle Experiment cores. 
The information obtained from these studies of neutron-flux distribution and, to a limited extent, of energy distribution in the EBWR, are useful for evaluation of fuel burnup, burnable poison effects, and radiation damage, and the determination of the most desirable conditions of reactor operation with respect to control parameters, i.e., control rod positions and soluble-poison concentration.

Since the application of specific neutron-flux data to a particular problem or area of interest is largely dependent on the parameters of the problem and the interests of the physicist or engineer making the study, it is proposed here to give as completely as possible the data and reactor parameters obtained, with a commentary on the data and the practical applications thereof. Application of the data to specific problems is left to the reader.

\subsection{Background}

Studies of neutron-flux distribution and energy spectra in reactors are the subject of many reports. $(2-6)$ The techniques, methods, and modifications thereof well outnumber the reactors studied. Power reactors, however, have received a limited amount of study, primarily because of the difficulty of access for the neutron detection equipment. Previous studies have been almost entirely limited to the use of foil materials having sufficiently long-lived activation products to accommodate both a long irradiation time and a long postirradiation time to allow for removal and analysis of the detectors. Obviously, there could be little provision for extensive study of neutron distribution or energy as a function of various reactor parameters. The first indication of such an extensive study, using wires with provision for ready insertion and removal from the Vallecitos Boiling Water Reactor, was by Carver and Morgan. (2) Results of that study have not been published, but the selection of radioactivants proposed by those authors undoubtedly will be used in future studies on EBWR. With the method developed for fast insertion and removal of actiration foils, and with the option of using cadmium covers, the door is opened for detailed study of power-reactor core neutronics, in spite of the high-pressure, hightemperature environment of the power-reactor core.

The EBWR is described briefly here; full details of the reactor design and operating parameters are available in the literature. $(7-11)$

The EBWR is a direct-cycle power reactor, with a heat dissipation capability of $100 \mathrm{MWt}$, as recently modified. It operates at 600 psi and $250^{\circ} \mathrm{C}\left(489^{\circ} \mathrm{F}\right)$. The reactor, in its $100-\mathrm{MWt}$ design, was fueled with both plate and spike fuel assemblies. The plate-type assemblies were of doublyenriched metallic uranium with Zircaloy-2 cladding. The spike assemblies were of highly-enriched uranium oxide pellets in Zircaloy tubing. Operational control was possible, both with the nine cruciform-shaped control 
rods, and with soluble poison (boric acid) dissolved in the coolant-moderator water. Fuel burnup compensation in the spike assemblies was provided by burnable poison (boron-stainless steel) strips affixed to the assemblies.

2. DETERMINATION OF NEUTRON-FLUX DISTRIBUTION IN EBWR

\subsection{Method for Foil Irradiation and Analysis}

The irradiation facilities, procedure, analytical method, and equipment are detailed in ANL-7011.(1)

The present study of the EBWR neutron-flux distribution was made by irradiating small, spherical (1/16-in. diameter), $1 \%$ cobalt-aluminum foils with and without $15-\mathrm{mil}$ cadmium covers (see Fig. 1) in preselected locations in the core for $30 \mathrm{~min}$. Using the technique previously mentioned, up to 60 such foils were simultaneously irradiated. The in-core locations for irradiation are shown in Fig. 2 .

(A)
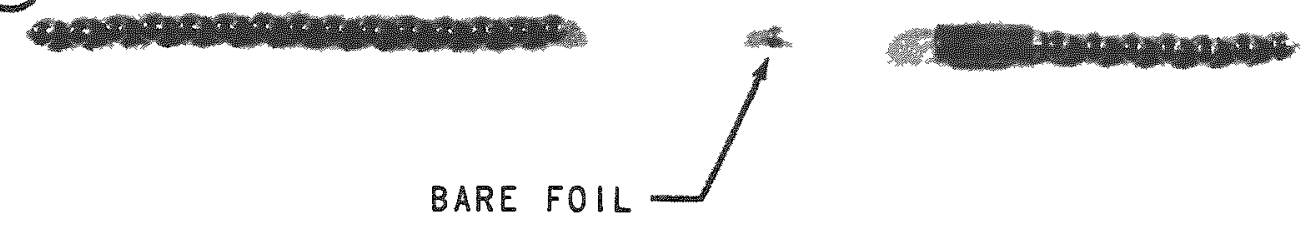

BARE FOIL

(B)

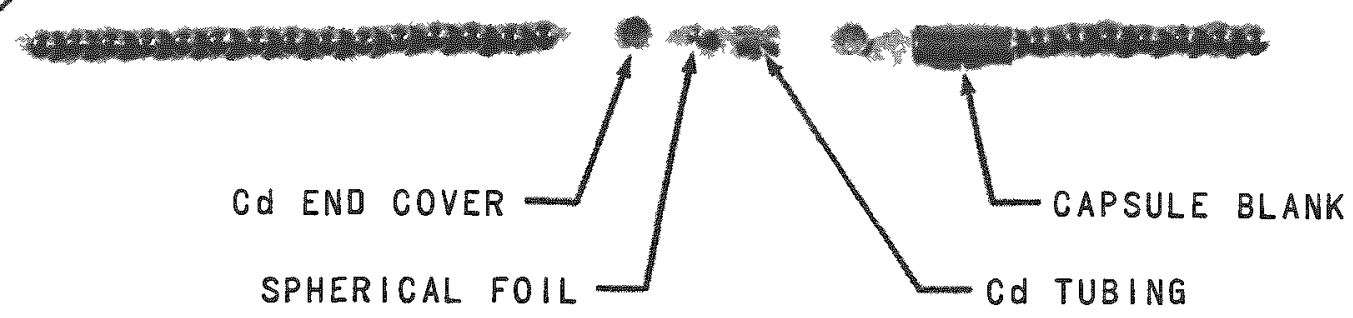

(C)

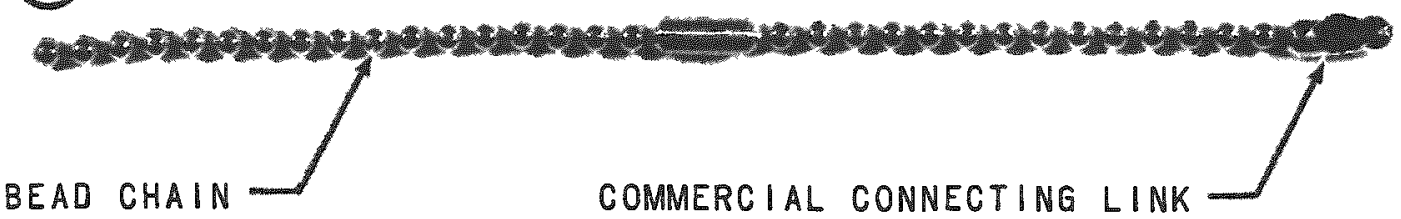

Fig. 1. Sample Assembly. (A) Partially Assembled, Bare Foil; (B) Partially Assembled, Cadmium-covered Foil; (C) Completed Assembly (Note Bead-chain Connector at Right End). 


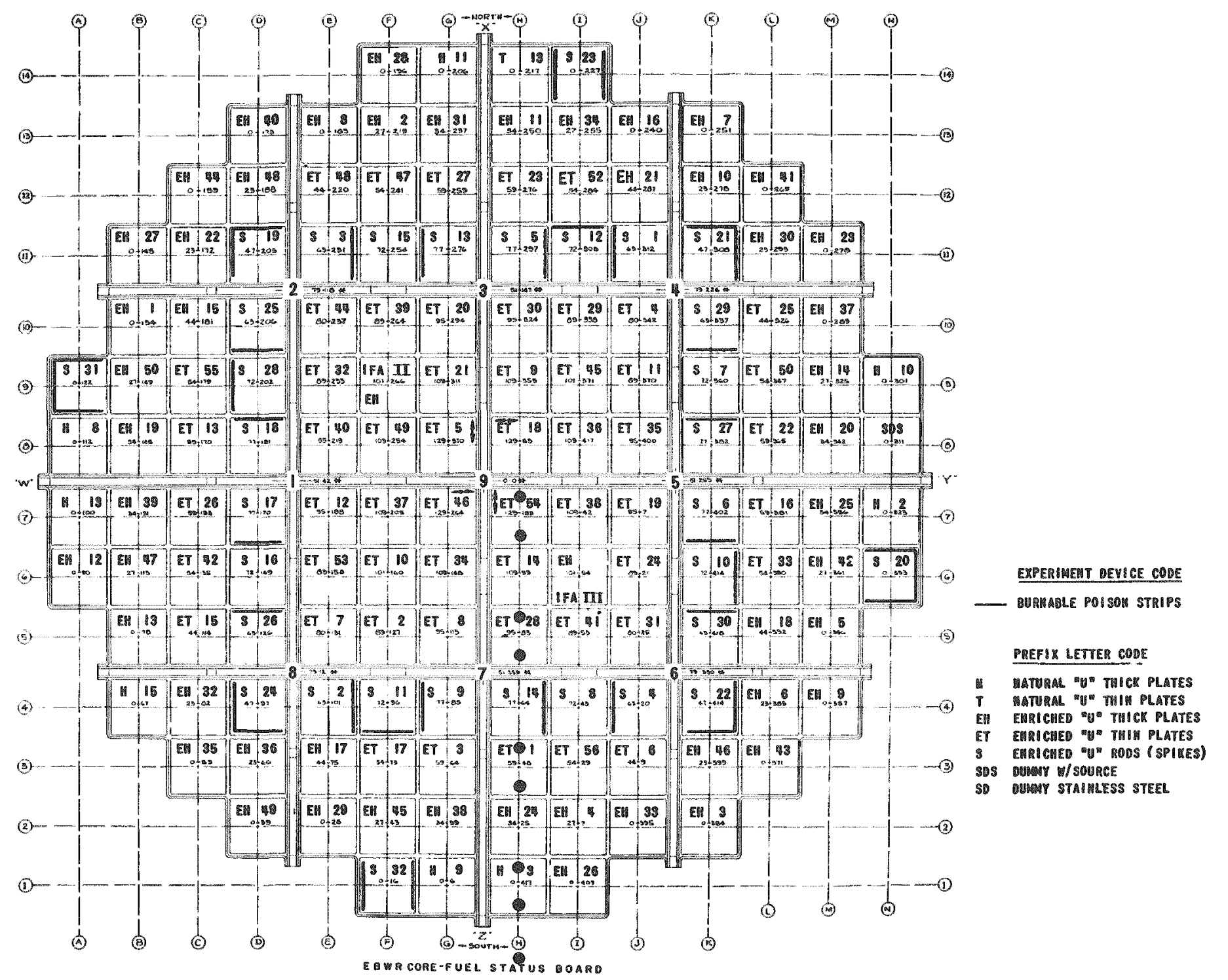

Fig. 2. Foil-irradiation Locations Used for Data Presented in Figs. 4-24, Inclusive. 
The induced $\mathrm{Co}^{60}$ activity was measured with a $\mathrm{NaI}(\mathrm{T} 1)$ scintillation detector and associated electronic equipment. Careful calibration of the

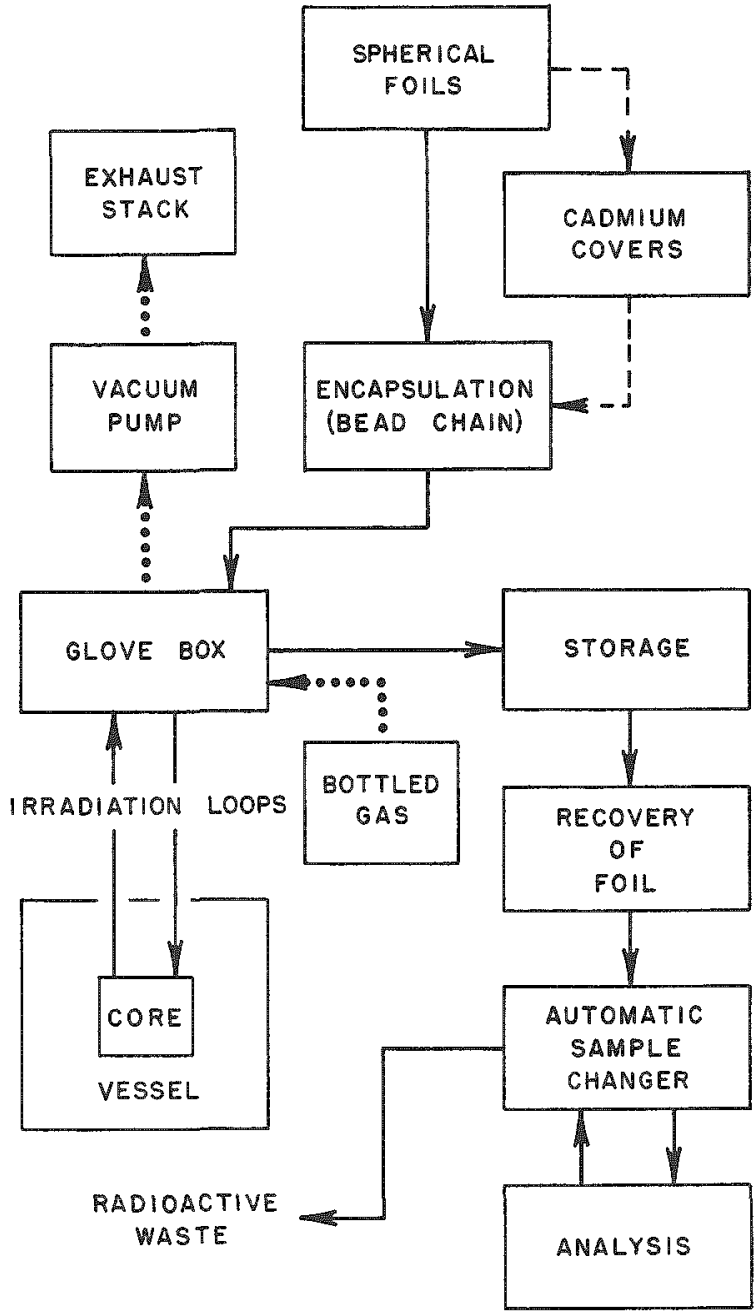

Fig. 3. Schematic Diagram of Irradiation-analysis Procedure Used in Study of EBWR Neutronflux Distribution detection equipment and the uniformity of the design and weight of the detector foils greatly simplified calculation of individual foil activities.

The cobalt concentration in the aluminum alloy was $1.01 \%$. The average weight of the activation foils was $0.00571 \mathrm{~g} \pm 1 \%$. The detection efficiency was determined from accurate radiochemical analysis of selected foils.

Figure 3 is a schematic diagram of the irradiation-analysis procedure.

\subsection{Calculation of Neutron-flux Levels from Foil Data}

In most cases, both bare and cadmium-covered foils were irradiated in identical core locations for a given set of reactor parameters. In a few cases, particularly where plant operating conditions limited personnel access to the reactor containment building, such as during high-power operation, it was possible to irradiate only bare samples. Because of the interest in these latter samples and the need for crosscomparison to similar samples irradiated at the other power levels, the first calculations used only the bare-foil data from all runs based on a of $36.0 \mathrm{~b}$. (12) The resultant neutron-flux values for each foil were plotted, relative to the irradiation position of that foil within a given fuel assembly or in the reactor downcomer. From a series of these axial neutron-flux plots for a given reactor operating condition, a neutron-flux isogram plot was constructed, with levels of multiples and decimal multiples of $10^{13} \mathrm{n} /\left(\mathrm{cm}^{2}\right)(\mathrm{sec})$.

Subsequent calculations used the cadmium-covered foil data, giving thermal and resonance (dE/E) flux values. The thermal flux was calculated in the usual way, using $\sigma$ equal to $26.0 \mathrm{~b}$ for the $250^{\circ} \mathrm{C}\left(489^{\circ} \mathrm{F}\right.$ ) reactor system [calculated according to Westcott(13)], where 


$$
\bar{\sigma}=\hat{\sigma} \sqrt{\left(\pi T_{0} / 4 T\right)}
$$

The isogram plots of the thermal neutron-flux levels were calculated from bare and cadmium-covered foil information, using a resonance integral of $49.3 \mathrm{~b}$ for the total epicadmium flux. (14) The resonance flux to $50 \mathrm{keV}$ was then obtained by integration of the logarithmic resonance interval between $0.4 \mathrm{eV}$ and $50 \mathrm{keV}$. No correction was made for $1 / \mathrm{V}$ contribution to the activity of the cadmium-covered cobalt foils.

Each calculation gave an appropriate point on an axial-flux plot, from which the respective neutron-flux isogram plots were prepared.

\section{DISCUSSION OF RESULTS}

The data obtained by cobalt foil irradiation in the EBWR during power operation have been assembled and presented in groupings according to the operating power level. Subgroupings were then made for different soluble-poison concentrations. The neutron-flux isogram plots obtained with both bare and cadmium-covered foil data are presented first (see Figs. 4 to 13), and those derived from bare foil information only follow (see Figs. 14 to 24). The irradiation conditions are summarized in Table I.

Table I

SUMRARY OF IRRADIATTON CONDITIONS FOR DATA

IN FIGS. + TO 24, INCLUSIVE

\begin{tabular}{|c|c|c|c|c|c|c|c|c|}
\hline \multirow{2}{*}{$\begin{array}{l}\text { Run } \\
\text { No. }\end{array}$} & \multirow{2}{*}{$\begin{array}{l}\text { Power } \\
\text { (Mwt) }\end{array}$} & \multicolumn{2}{|c|}{$\begin{array}{l}\text { Rod Positions } \\
\text { (in.) }\end{array}$} & \multirow{2}{*}{$\begin{array}{c}\mathrm{H}_{3} \mathrm{BO}_{3} \\
\text { Concentration } \\
\text { (ppri) }\end{array}$} & \multicolumn{2}{|c|}{$\begin{array}{l}\text { Foils } \\
\text { Activated }\end{array}$} & \multirow{2}{*}{ Calculated Flux } & \multirow{2}{*}{$\begin{array}{l}\text { Fig. } \\
\text { No. }\end{array}$} \\
\hline & & Nos. $1-8$ & No. 9 & & $\mathrm{Co}$ & $\mathrm{Co}-\mathrm{Cd}$ & & \\
\hline 1 & 21 & 22 & 22 & 25 & $X$ & $\mathrm{X}$ & $\begin{array}{l}\text { Thermal } \\
\text { Resonance } \\
\text { (Bare Co Only) }\end{array}$ & $\begin{array}{r}4 \\
5 \\
14\end{array}$ \\
\hline 2 & 41.2 & 26 & 26 & 25 & $x$ & $x$ & $\begin{array}{l}\text { Thermal } \\
\text { Resonance } \\
\text { (Bare Co Only) }\end{array}$ & $\begin{array}{r}6 \\
7 \\
15\end{array}$ \\
\hline 3 & 10 & 48 & 43 & 900 & $\mathrm{x}$ & & (Eare Co Only) & 16 \\
\hline 4 & 42 & 48 & 44.5 & 1200 & $x$ & $\mathrm{x}$ & $\begin{array}{l}\text { Thermal } \\
\text { Resonance } \\
\text { (Bare Co Only) }\end{array}$ & $\begin{array}{r}8 \\
9 \\
17\end{array}$ \\
\hline 5 & 62 & 30.5 & 30.5 & 25 & $\mathrm{x}$ & $\mathrm{X}$ & $\begin{array}{l}\text { Thermal } \\
\text { Resonance } \\
\text { (Bare Co Only) }\end{array}$ & $\begin{array}{l}10 \\
11 \\
18\end{array}$ \\
\hline 6 & 58 & 48 & 30 & 120 & $X$ & $\mathrm{X}$ & $\begin{array}{l}\text { Thermal } \\
\text { Resonance } \\
\text { (Bare Co Only) }\end{array}$ & $\begin{array}{l}12 \\
13 \\
19\end{array}$ \\
\hline$\vec{i}$ & 00 & 18 & 48 & 935 & $\mathrm{x}$ & & (Bare Co Only) & 20 \\
\hline 8 & $78-80$ & 48 & \pm 8 & 27 & $\mathrm{X}$ & & (Bare Co Only) & 21 \\
\hline 9 & 72 & 48 & 48 & 225 & $\mathrm{X}$ & & (Bare Co Only) & 22 \\
\hline 10 & 75 & 40.5 & 30 & 290 & $\mathrm{X}$ & & (Bare $\mathrm{Co}_{0}$ Only) & 23 \\
\hline 11 & 80 & 48 & 48 & 540 & $x$ & & (Bare Co Only) & 24 \\
\hline
\end{tabular}




\subsection{Effect of Reactor Power on Neutron-flux Distribution and Energy}

\subsubsection{In Absence of Soluble Poison}

Considerable data were obtained at a variety of power levels where the concentration of soluble poison was at its lowest normal operating level and was practically insignificant (25 ppm). Power levels studied were $\sim 20 \mathrm{MWt}$ (Figs. 4, 5, and 14), 40 MWt (Figs. 6, 7, and 15), $60 \mathrm{MWt}$ (Figs. 10, 11, and 18), and $\sim 80 \mathrm{MWt}$ (Fig. 21). Both bare and cadmiumcovered foil data were available for all but the $80-$ MWt condition.

In the absence of soluble poison at powers up to $60 \mathrm{MWt}$, the control rods were inserted a significant distance into the core, as shown in the respective figures. This resulted in peak power production in the lower 12 in. of the fuel meat, with a rapid drop in power vertically through the core. The power peak is displaced from the core center, probably due to the effect of the central control rod. Whether the spike assembly ring contributes significantly to this displacement is subject to question. There is evidence that the vertical distribution of flux and, hence, power in the spike assemblies is more limited than in adjacent assemblies. This might be expected in the presence of the burnable poison strips attached to the spike assemblies.

A significant the rmal-neutron reflux peak is observed at the bottom of the core, with flux levels approaching that of the peak-power zone. As expected, similar peaks are absent from the plots of higherenergy neutrons.

The peak flux of resonance neutrons is located at a higher point in the core than is the area of peak thermal neutron flux, with the control rods having a more observable effect on the radial distribution.

Operation of the 100-MWt EBWR core at powers of $60 \mathrm{MWt}$ or less in absence of soluble poison resulted in an impractical (from a fuel economy point of view), pancake power distribution Such a distribution. could be of practical value, however, if the assemblies were designed to be inverted during a portion of their in-core life, as was initially proposed for EBWR Core II. (15)

The neutron flux incident upon the reactor vessel is not a linear function of the power level since the effect of raising the power level was primarily shown as increasing the height rather than the diameter of the effective core volumes.

\subsubsection{In Presence of Soluble Poison}

Irradiations were made at $\sim 40$ and $\sim 60 \mathrm{MWt}$ with very similar soluble-poison concentrations $(\sim 900 \mathrm{ppm})$, and at $\sim 80 \mathrm{MWt}$ with a somewhat 


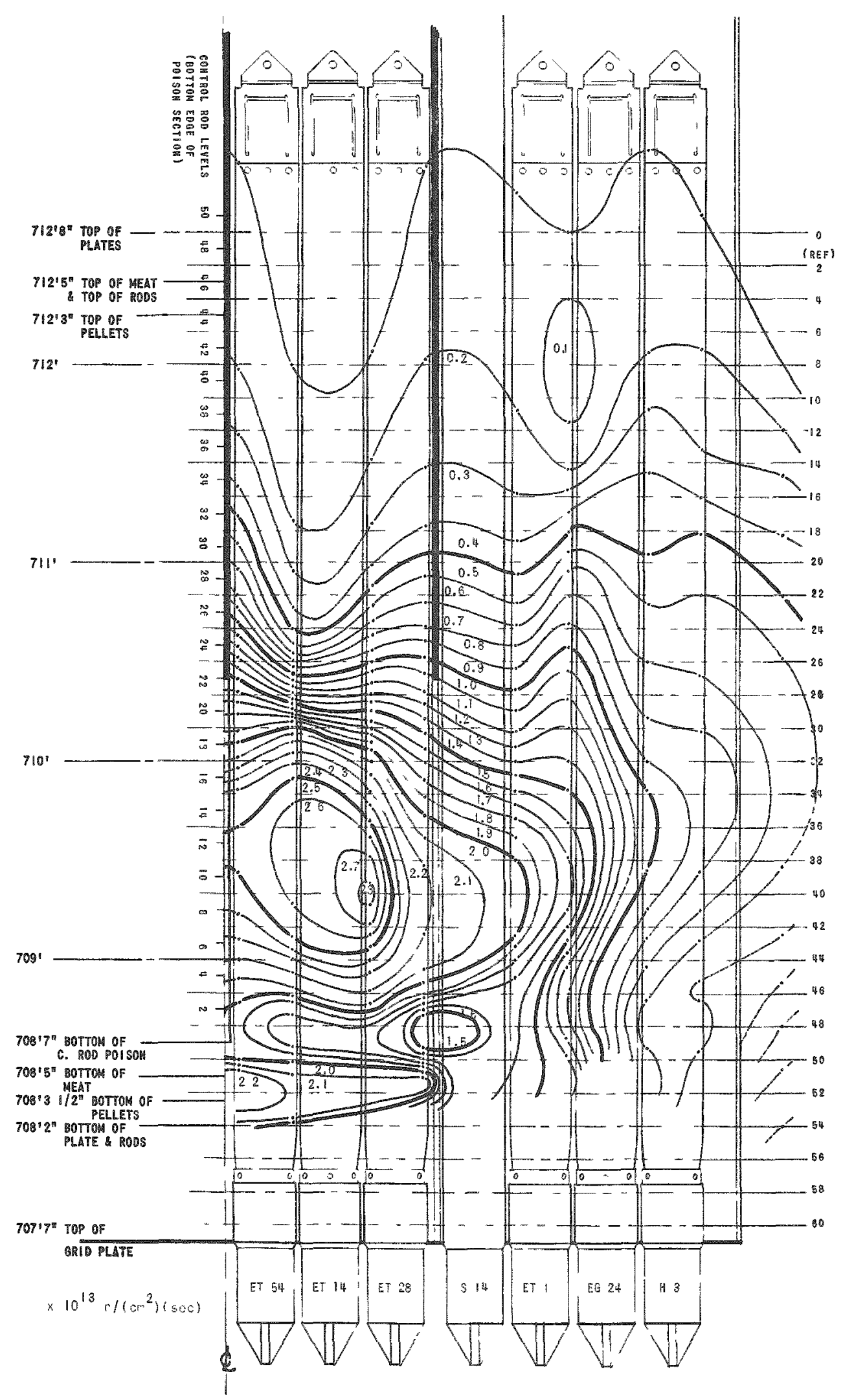

$112-2786$ Rev.

Fig. 4. Thermal-neutron-flux Isogram Plot for Reactor Power of $21 \mathrm{MWt}$, Soluble-poison Concentration of $25 \mathrm{ppm}$ as Boric Acid 


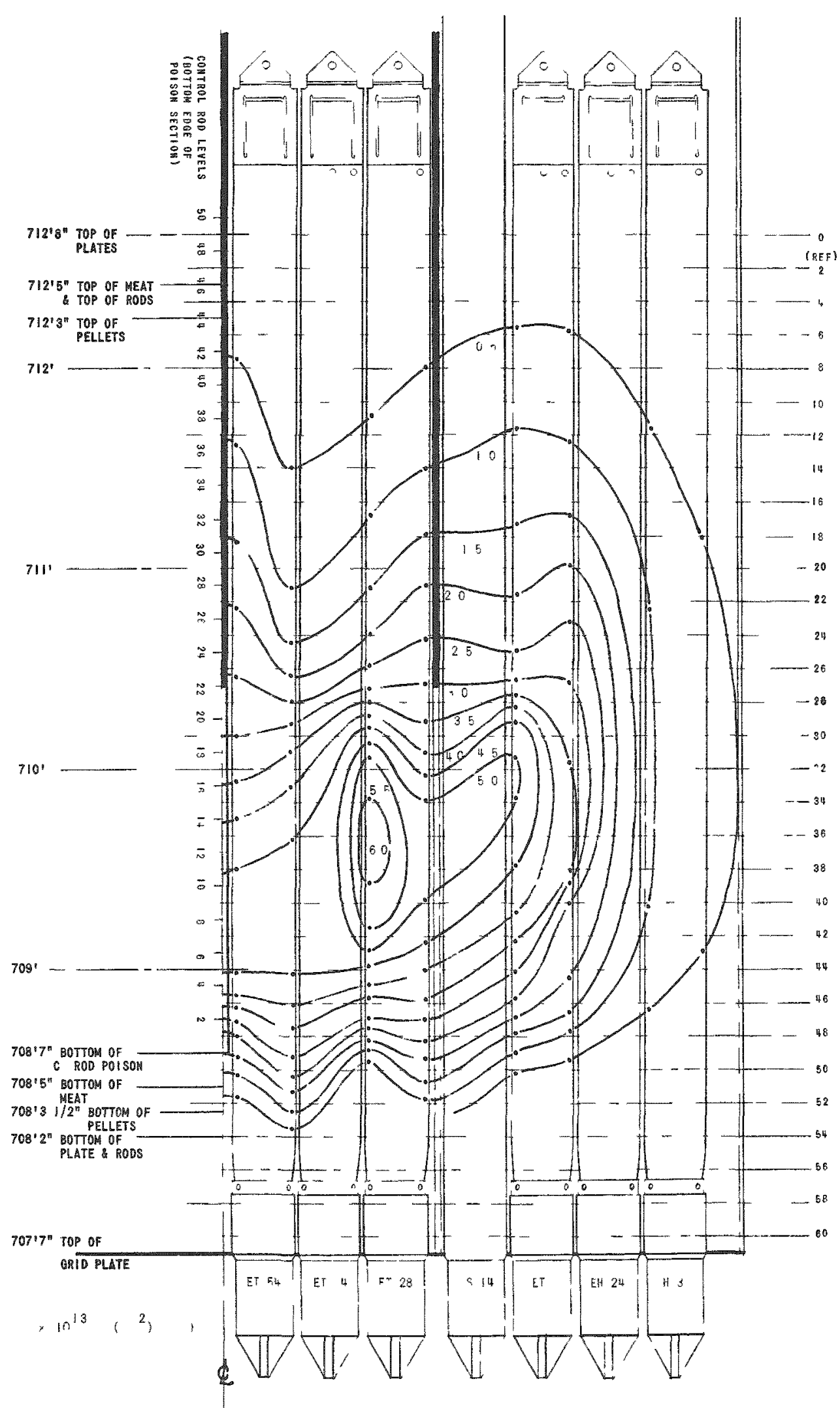

Fig. 5. Resonance-neutron-flux Isogram Plot for Reactor Power of $21 \mathrm{MWt}$, Soluble-poison Concentration of 25 ppm as Boric Acid 


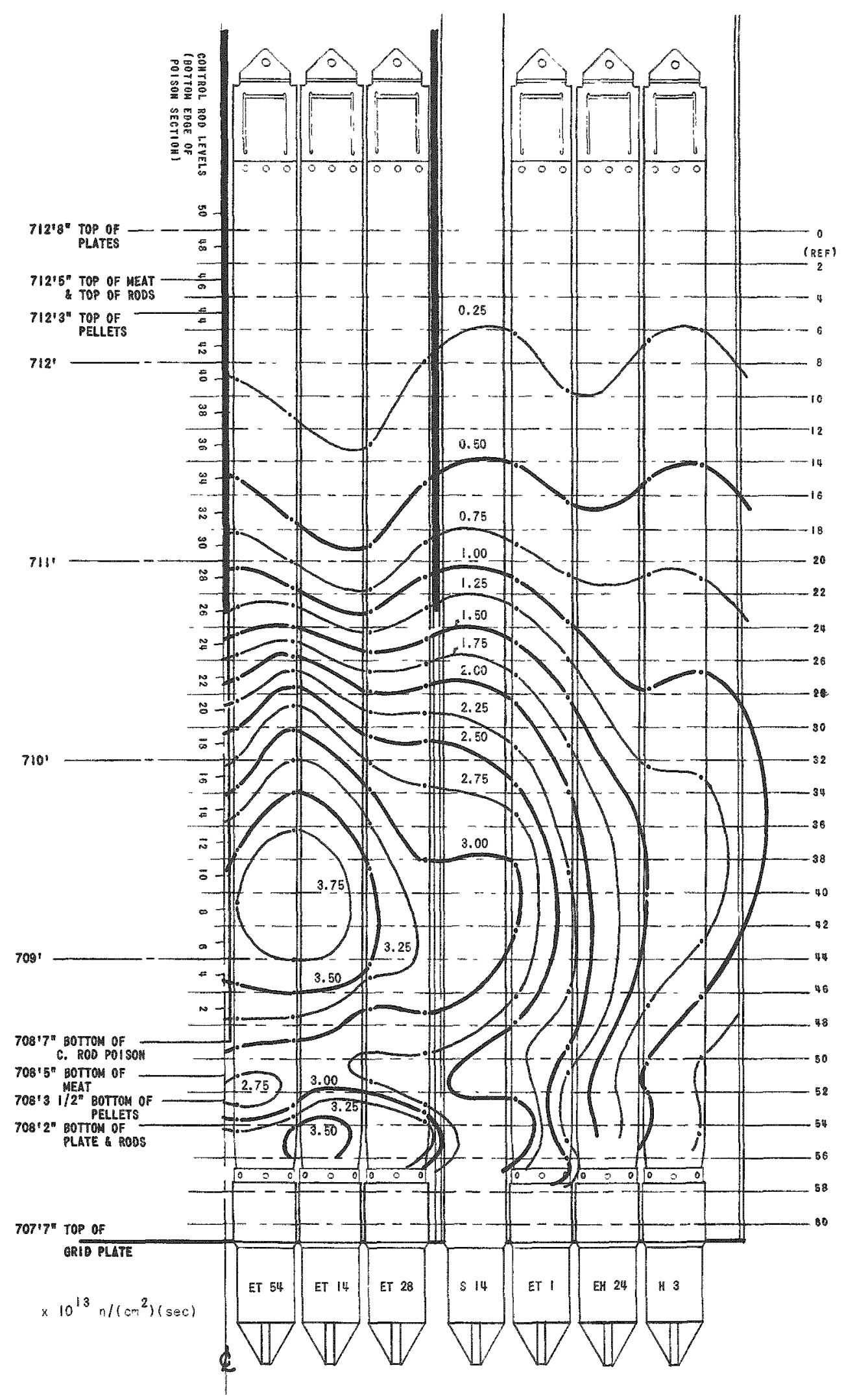

112-2620 Rev.

Fig. 6. Thermal-neutron-flux Isogram Plot for Reactor Power of 41.2 MWt, Soluble-poison Concentration of 25 ppm as Boric Acid 


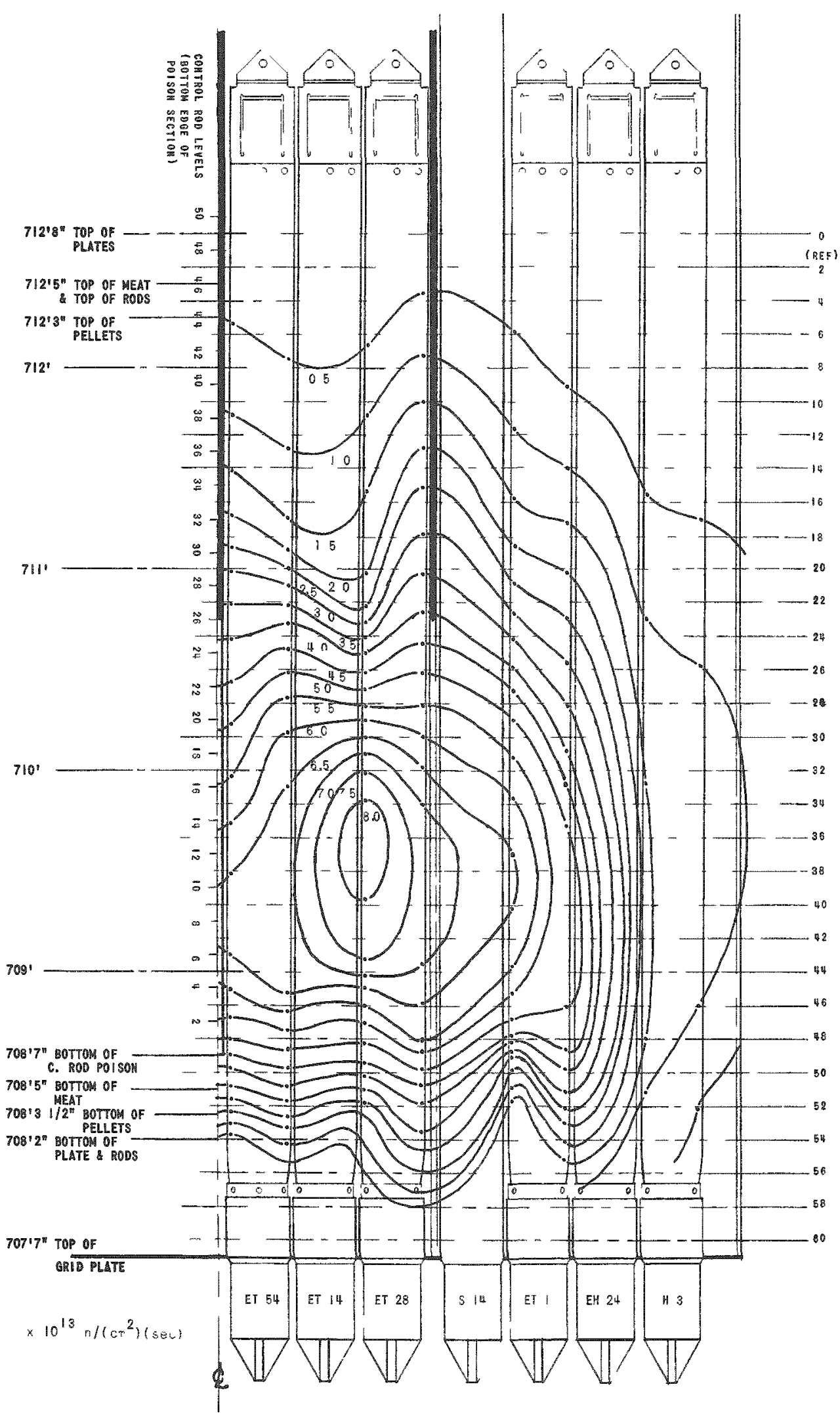

112-2784 Rev.

Fig. 7. Resonance-neutron-flux Isogram Plot for Reactor Power of 41.2 MWt, Soluble-poison Concentration of 25 ppm as Boric Acid 
lower concentration (540 ppm). The resultant neutron-flux plots are shown in Figs. 16, 20, and 24, respectively. No cadmium-covered foil data were obtained on any of the runs.

The most obvious effect due to power-level variation in the absence of soluble poison was that due to withdrawal of the controls rods; i.e., the effective core is expanded axially. With large amounts of soluble poison, the control rods are already withdrawn to near their effective limits so that changes in power level merely change the neutron-flux level rather uniformly over the core. The radial displacement of the peak flux area from the core center is not present at 40 and $60 \mathrm{MWt}$; however, it is observed at $80 \mathrm{MWt}$. This may be partially because, as mentioned above, the concentration of soluble poison was significantly lower than for the 40- and 60-MWt runs.

At $40 \mathrm{MWt}$, the neutron flux at the reactor vessel appears to be considerably less than at the higher power levels.

\subsection{Effect of Soluble-poison Concentration on Neutron-flux Distribution and Energy}

Since foils were irradiated in the EBWR with several different concentrations of soluble poison at $\sim 40, \sim 60$, and $\sim 80 \mathrm{MWt}$ (though both bare and cadmium-covered foils were irradiated with different solublepoison concentrations only at $\sim 40$ and $\sim 60 \mathrm{MWt}$ ), one can evaluate the effect of the uniformly-distributed $1 / V$ poison on the neutronics of the reactor.

\section{2 .1 At $\sim 40 \mathrm{MWt}$}

Irradiations were made at concentrations of 25,900 , and 1200 ppm (as boric acid), although only bare folls were irradiated at the 900-ppm level. Since both thermal and epicadmium (resonance) information is available for the reactor at $40 \mathrm{MWt}$ and at 25- and 1200-ppm soluble poison, a comparison of these data is interesting.

Comparing Figs. 6 and 7 with Figs. 8 and 9, respectively, shows that the presence of soluble poison has allowed almost complete withdrawal of the control rods, with a resultant shift upwards of the peak flux area. The peak thermal-neutron flux has been reduced by nearly a third [from $3.75 \mathrm{x}$ $10^{13}$ to $\left.2.6 \times 10^{13} \mathrm{n} /\left(\mathrm{cm}^{2}\right)(\mathrm{sec})\right]$, and the peak area has been spread axially. A much greater portion of the integrated flux is located in the outer fuel assemblies, giving a more uniform radial-power distribution. The neutron flux, both thermal and resonance, incident on the reactor vessel was significantly lower in the presence of boric acid, even though the effective core volume with the soluble poison was much enlarged. 


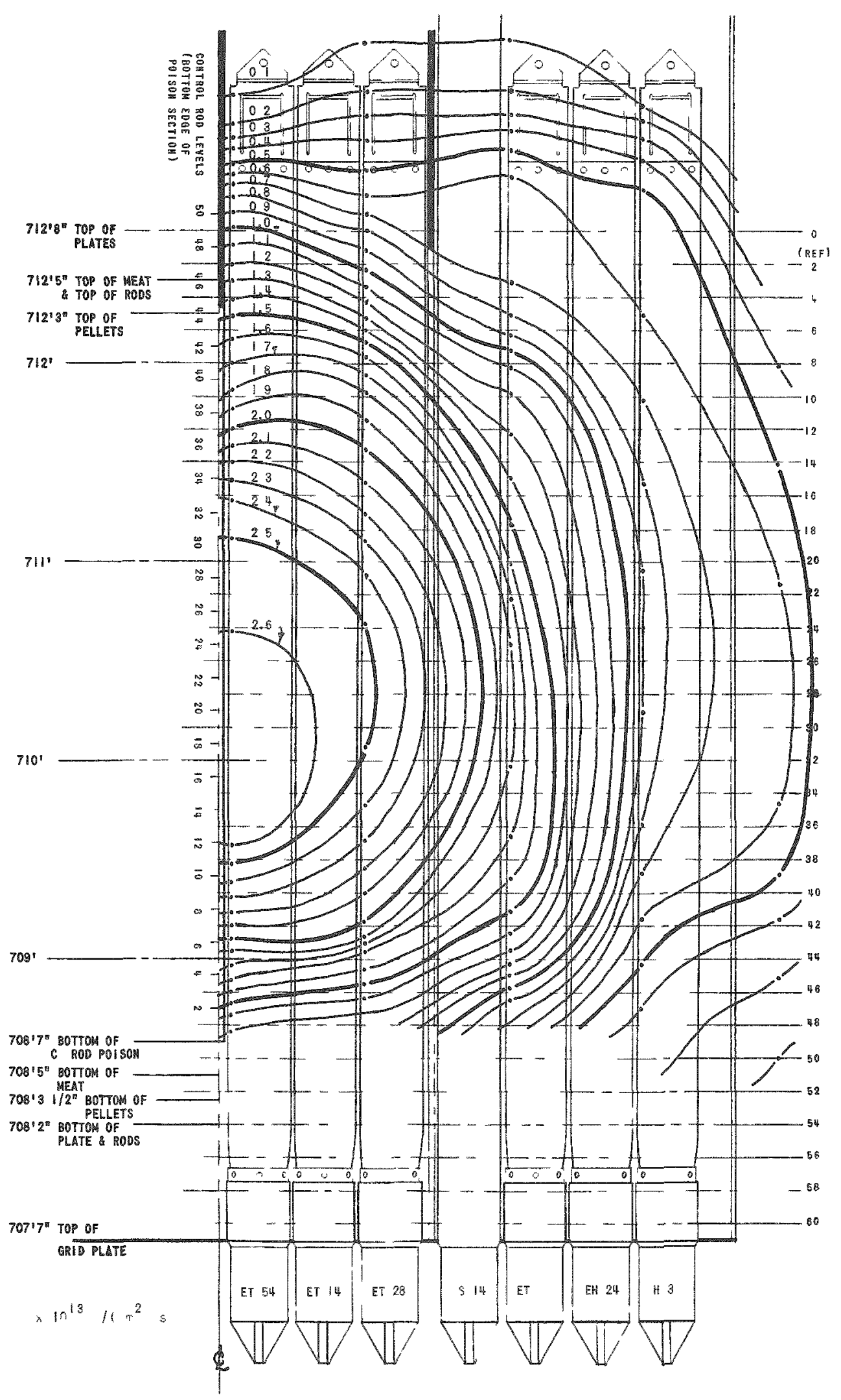

112-2626 Rev.

Fig. 8. Thermal-neutron-flux Isogram Plot for Reactor Power of $42 \mathrm{MWt}$, Soluble-poison Concentration of $1200 \mathrm{ppm}$ as Boric Acid 


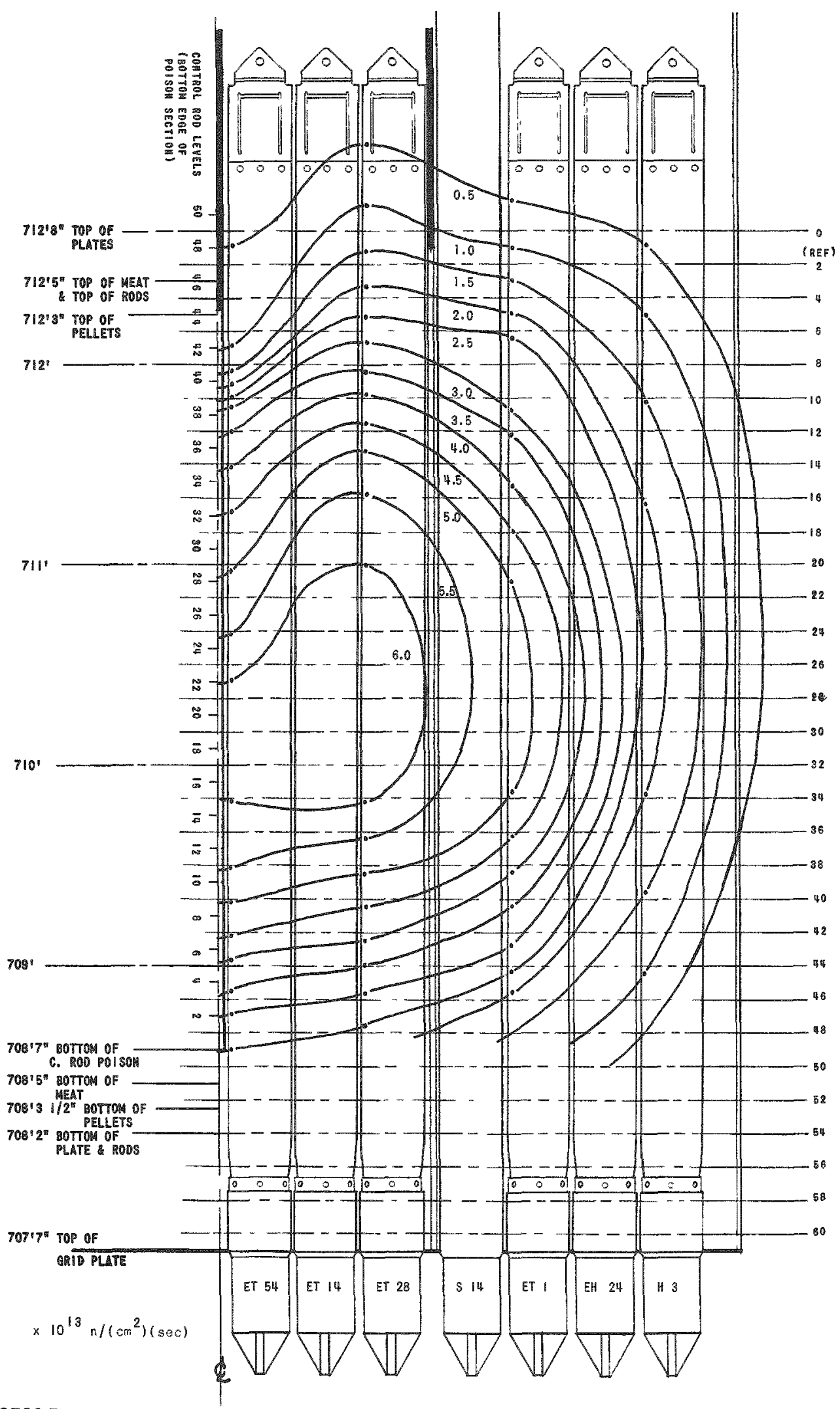

$112-2783$ Rev

Fig. 9. Resonance-neutron-flux Isogram Plot for Reactor Power of $42 \mathrm{MWt}$, Soluble-poison Concentration of $1200 \mathrm{ppm}$ as Boric Acid 
Figures 15, 16, and 17, which were constructed from bare-foil data only, indicate the intermediate concentration level of $900-p p m$ soluble poison at $\sim 40 \mathrm{MWt}$. Though the peak flux is higher (as expected) than for a $1200-p p m$ concentration, the flux distribution through the core is quite uniform, and the neutron flux incident on the reactor vessel is much lower than in the absence of the soluble porson

\section{2 .2 At $\sim 60 \mathrm{MWt}$}

At $\sim 60 \mathrm{MWt}$, as at $40 \mathrm{MWt}$, one of the three sets of data does not include cadmium-covered foil information The difference in solublepoison concentration is much smaller for the other two sets (25 and $120 \mathrm{ppm}$ ), and the control rod configuration for the run with 120 -ppm soluble poison was quite unusual due to rod oscillation studies being performed. Even so, the flux distribution, both thermal and resonance, was improved (see Figs. 10,11, 12, and 13). The peak neutron flux was reduced by $20 \%$, and the peak flux area was broadened and shifted upwards Time did not permit a determination of the effect the lower position of the center control rod (No 9) had on the distribution.

Figures 11 and 13 of the resonance ilux, and particularly the $2.0 \times 10^{13} \mathrm{n} /\left(\mathrm{cm}^{2}\right)(\mathrm{sec})$ isogram levels at the maximum radial positions, indicate that the addition of only $\sim 100 \mathrm{ppm}$ of boric acjd to the coolantmoderator water provided some protection to the reactor vessel. in addition to its beneficial core-neutronics effects Th1s effect may have been enhanced by the position of the center control rod

A comparison of the bare foil data presented in Figs, 18, 19, and 20 for 25-, 120-, and 925-ppm soluble poison, respectively, all at approximately $60 \mathrm{MWt}$, shows that much more of the advantage of soluble poison on the neutron-flux distribution was realized in the first $-100-p p m$ addition than in the additional $\sim 800-$ ppm addition. This assumes that the position of the central control rod at $120 \mathrm{ppm}$ did not greatly affect that flux distribution data. With the higher concentration, the peak flux is lowered and the area is enlarged and relocated higher in the core The presence of soluble poison has definitely improved the neutron flux distribution

\section{At 72 to $80 \mathrm{MWt}$}

Four sets of data were obtained during this high-power operation of EBWR; however, personnel access limitation into the reactor containment building limited the irradiations to bare foils only The reactor was operating in a unique manner(11) at these powers in that an unusually large amount of water was entrained in the effluent steam. This water, after being cooled in the condenser, was returned to the reactor in a manner similar to that in dual-cycle boiling reactor systems Since the amount of carry-over was a direct function of the water level in the reactor, operation at any given power could be accomplished, with a variety of control rod positions. dependent almost entirely on the subcooling resulting from the return of large quantities of the cold water from the condenser 


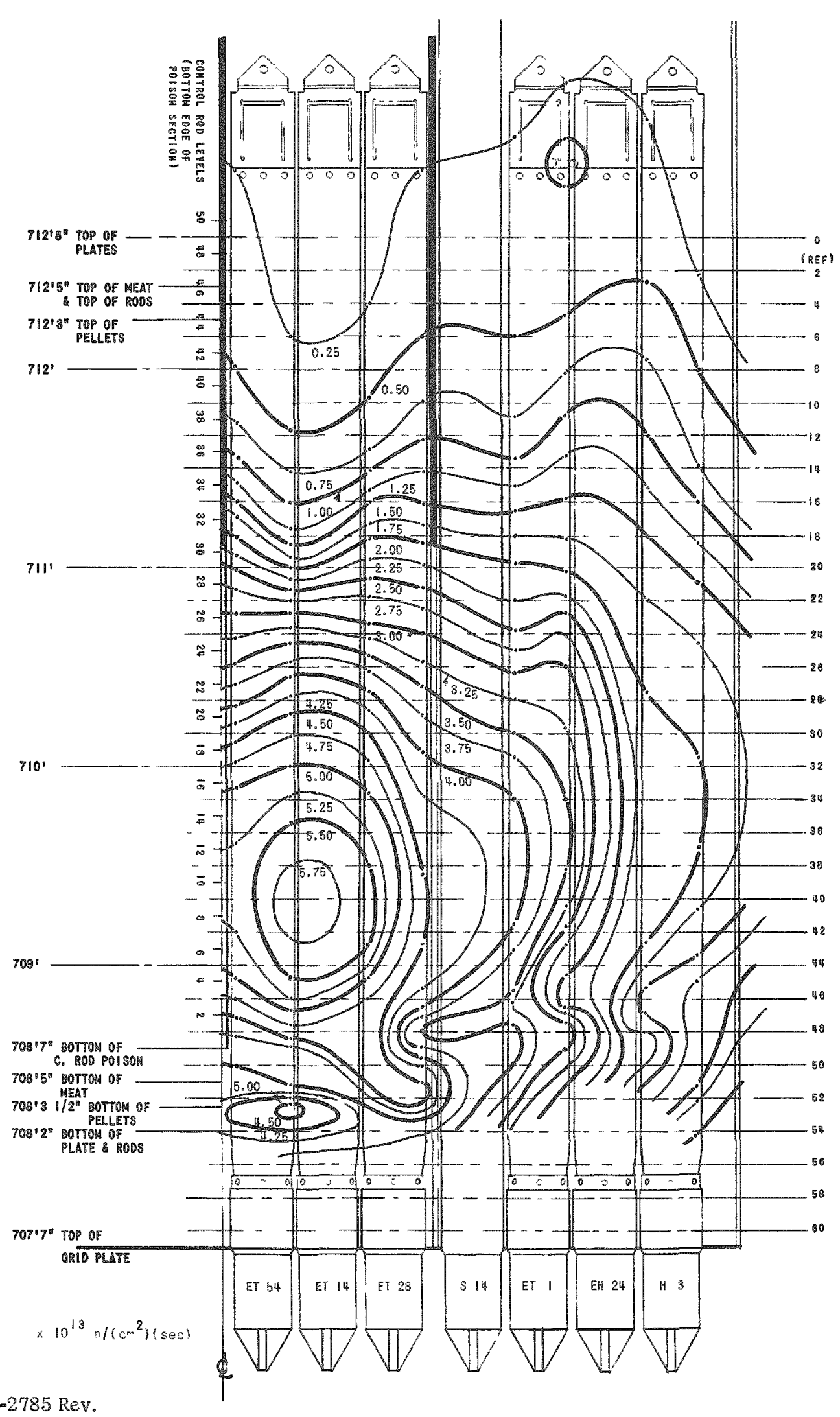

Fig. 10. Thermal-neutron-flux Isogram Plot for Reactor Power of $62 \mathrm{MWt}$, Soluble-poison Concentration of 25 ppm as Boric Acid 


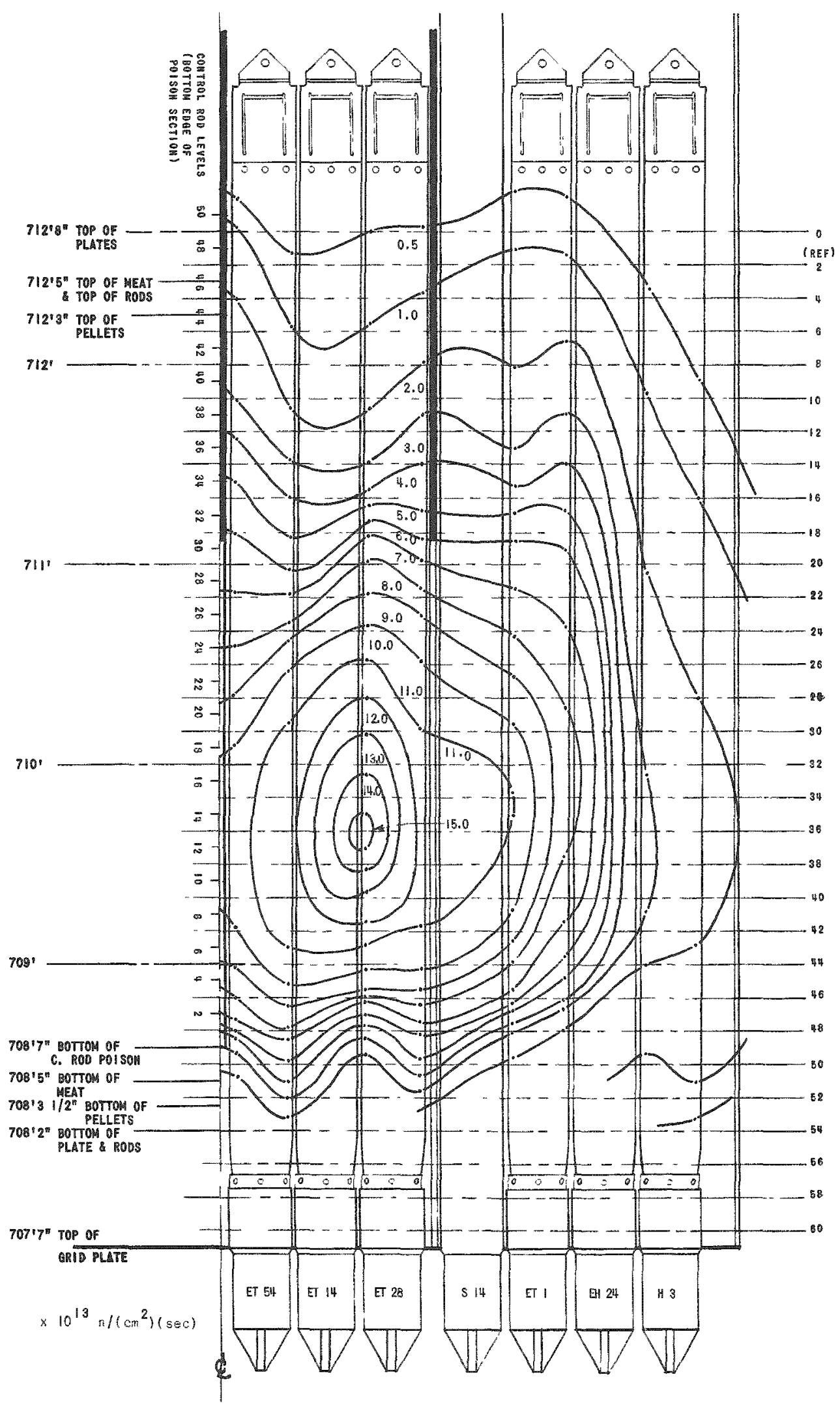

Fig. 11. Resonance-neutron-flux Isogram Plot for Reactor Power of 62 MWt, Soluble-poison Concentration of 25 ppm as Boric Acid 


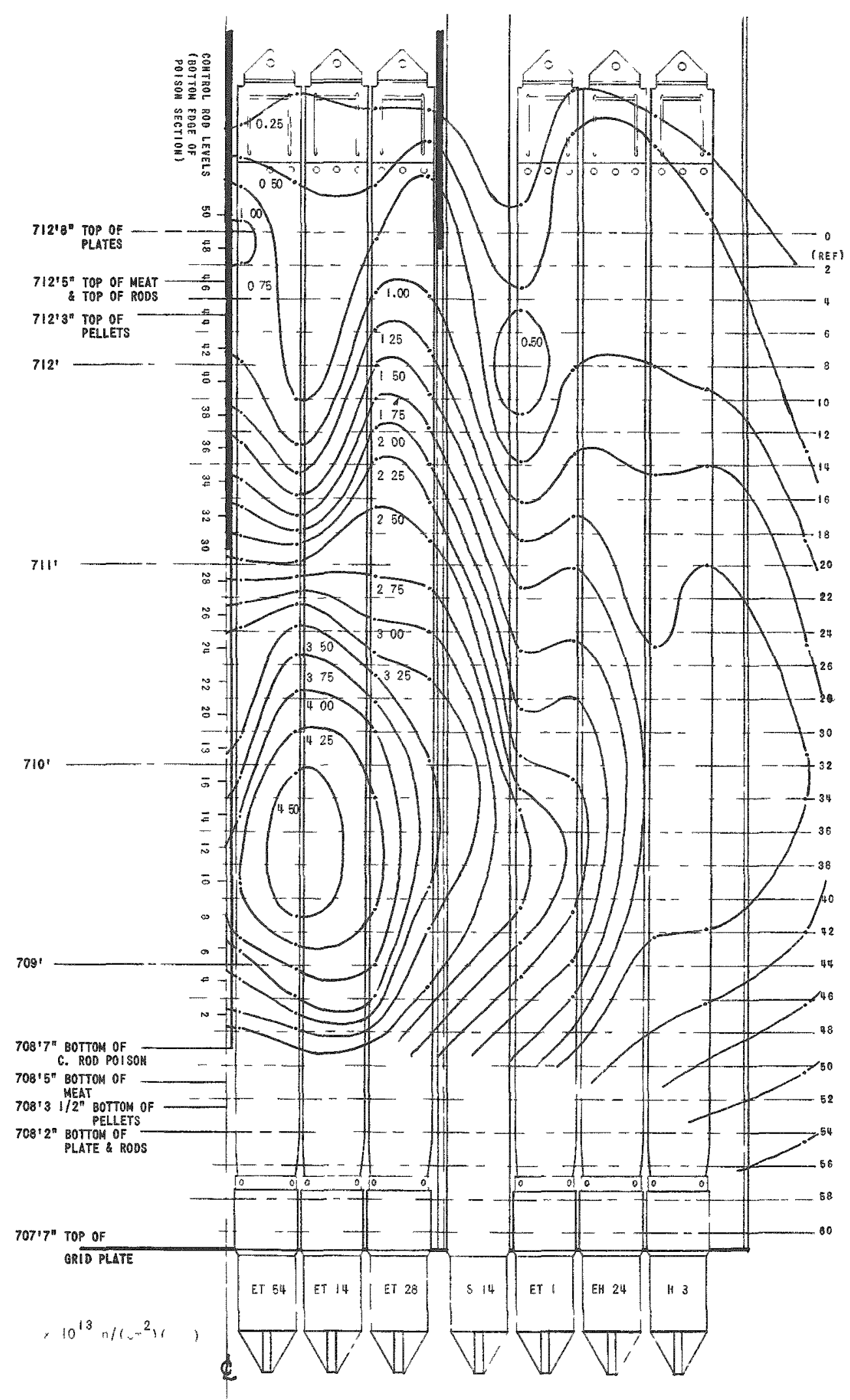

Fig. 12. Thermal-neutron-flux Isogram Plot for Reactor Power of $58 \mathrm{MWt}$, Soluble-poison Concentration of 120 ppm as Boric Acid 


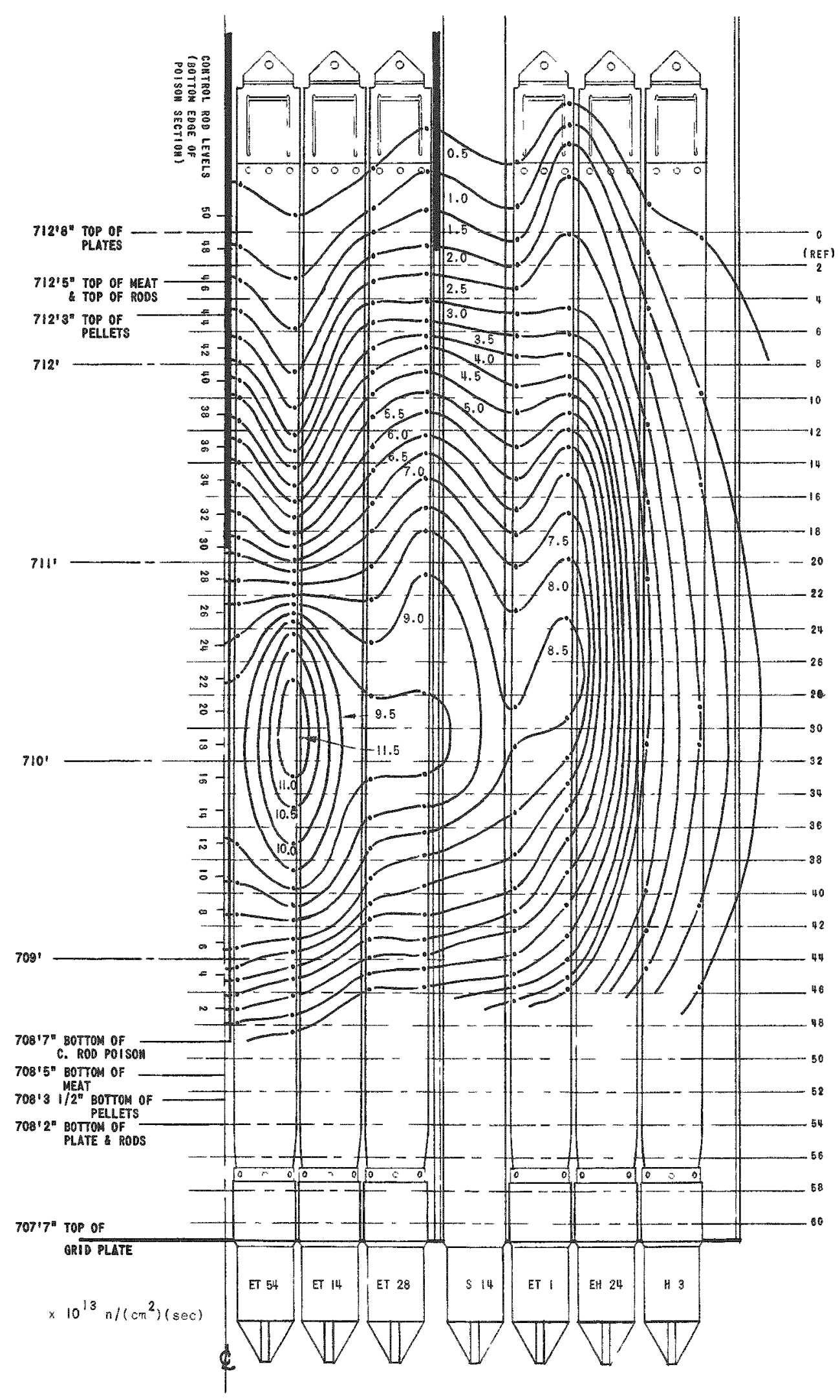

Fig. 13. Resonance-neutron-flux Isogram Plot for Reactor Power of $58 \mathrm{MWt}$, Soluble-poison Concentration of 120 ppm as Boric Acid 


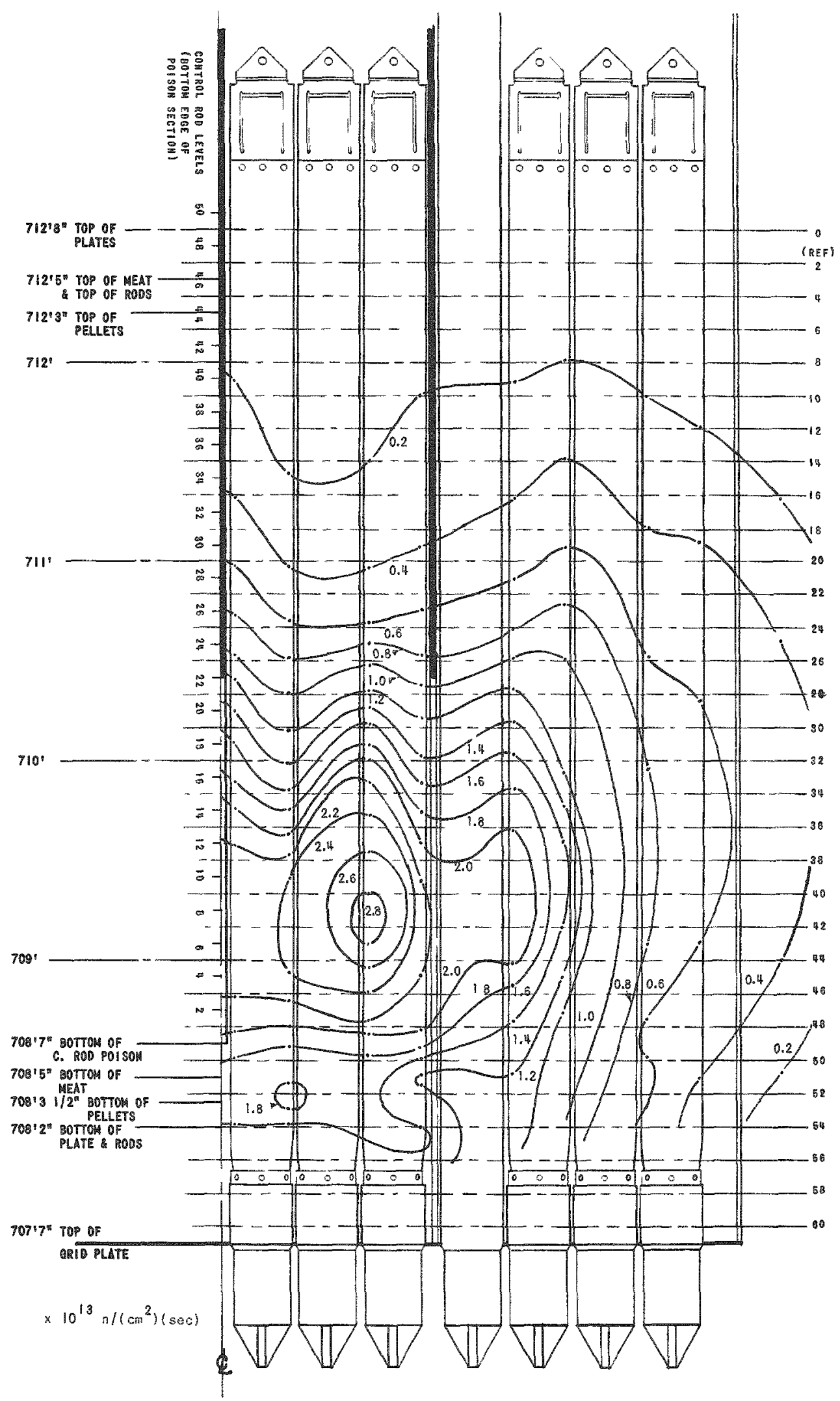

Fig. 14. Neutron-flux Isogram Plot Determined from Bare Cobalt Foil Activation Only, for Reactor Power of $21 \mathrm{MWt}$, Soluble-poison Concentration of $25 \mathrm{ppm}$ as Boric Acid 


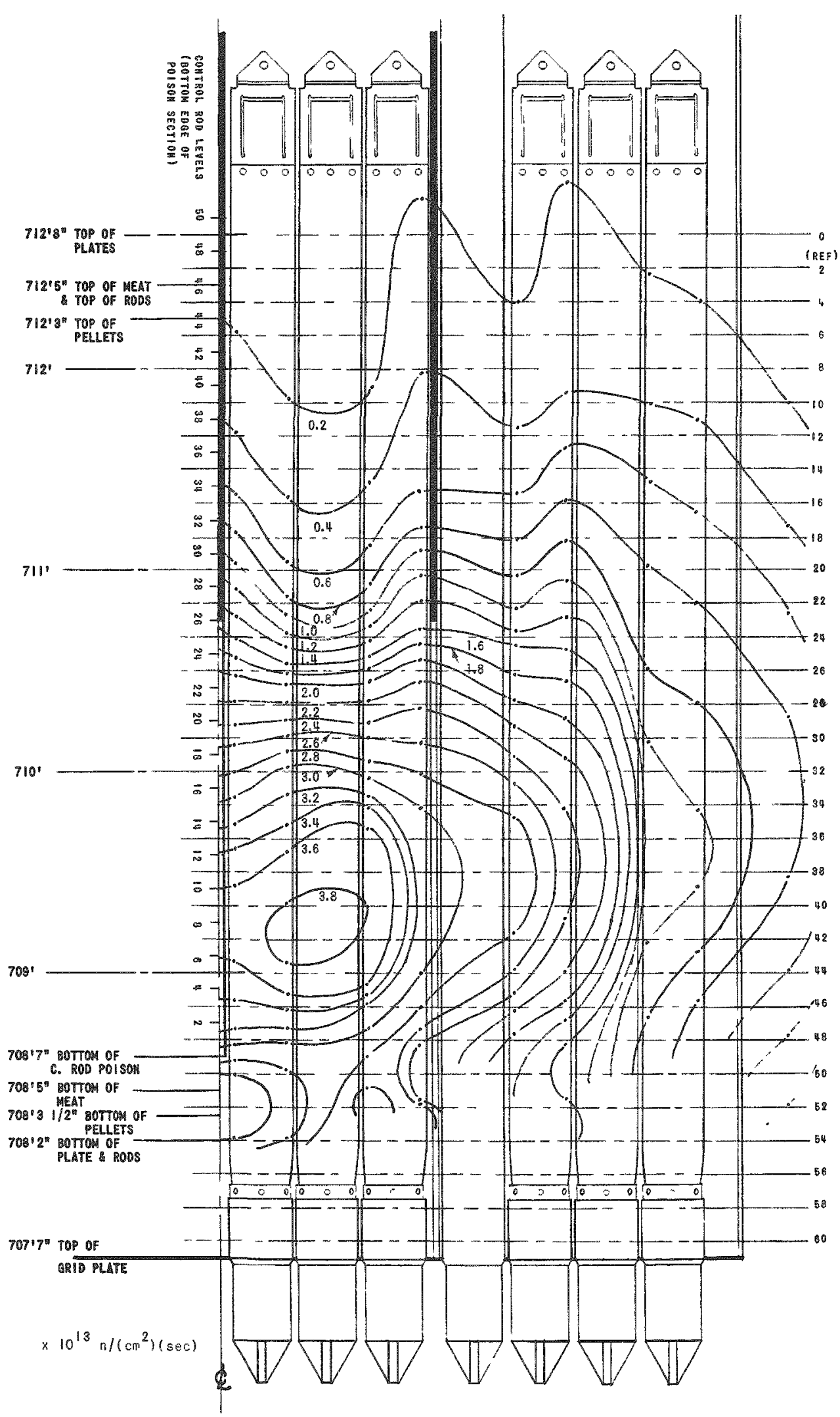

Fig. 15. Neutron-flux Isogram Plot Determined from Bare Cobalt Foil Activation Only, for Reactor Power of $41.2 \mathrm{MWt}$, Soluble-poison Concentration of $25 \mathrm{ppm}$ as Boric Acid 


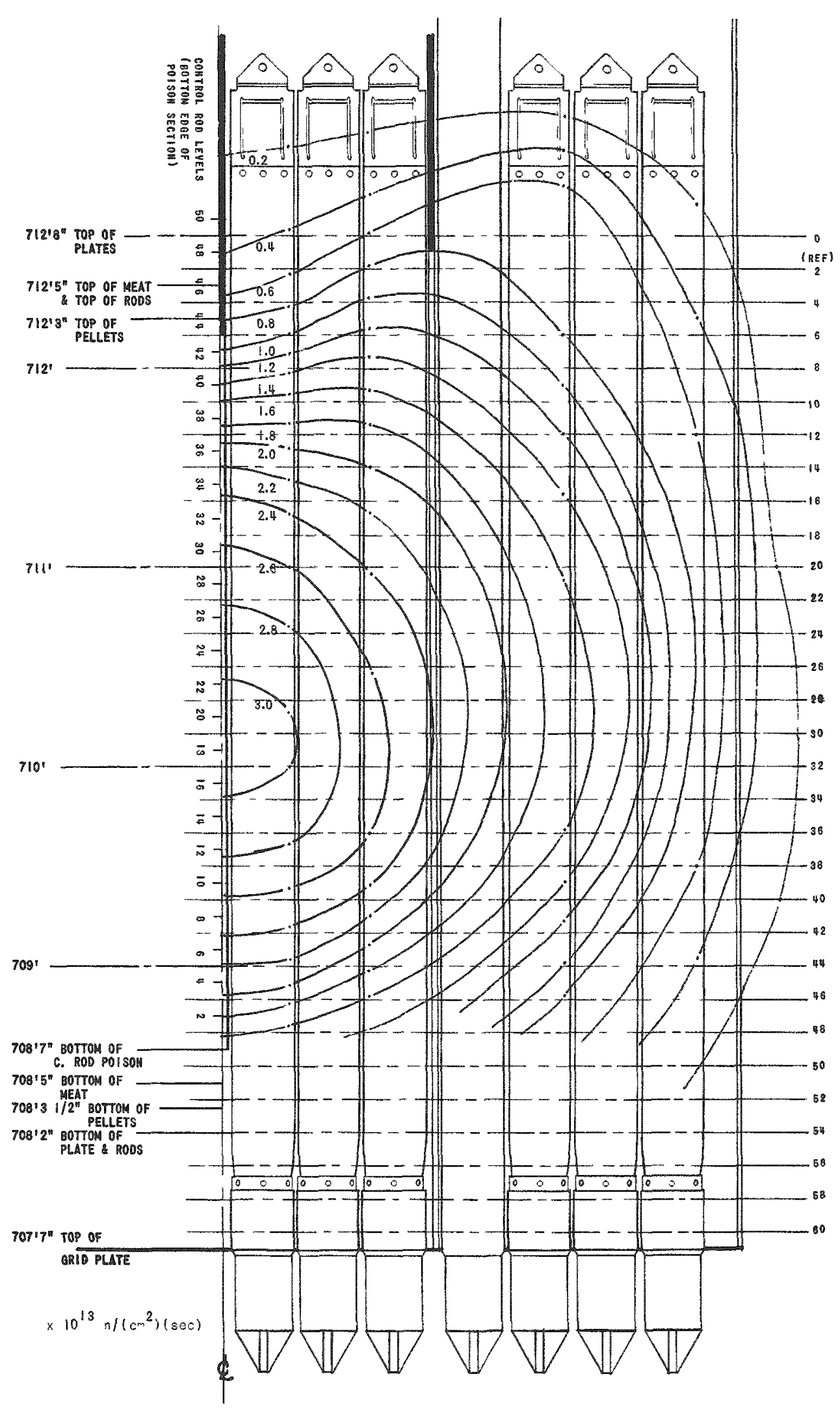

Fig. 16. Neutron-flux Isogram Plot Determined from Bare Cobalt Foil Activation Only, for Reactor Power of $40 \mathrm{MWt}$, Soluble-poison Concentration of 900 ppm as Boric Acid 


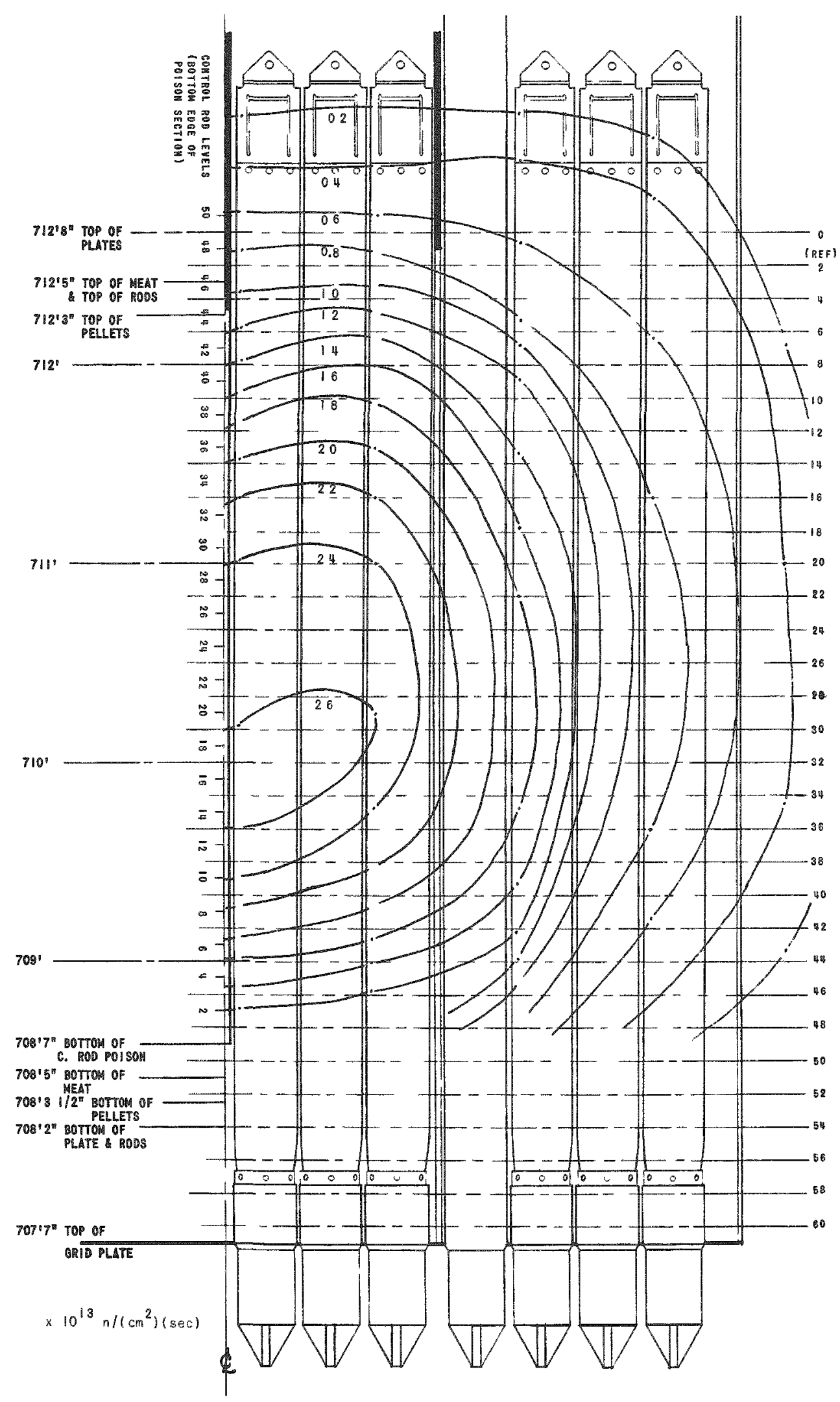

Fig. 17. Neutron-flux Isogram Plot Determined from Bare Cobalt Foil Activation Only, for Reactor Power of $42 \mathrm{MWt}$, Soluble-poison Concentration of $1200 \mathrm{ppm}$ as Boric Acid 
This complex operation, with the introduction of another variable (that of subcooling due to carry-over as a function of reactor water level) complicated the analysis of the data presented in Figs. 21 to 24, for 72 - to $80-M W t$ operation. One is limited to observations of the modification of the overall effective core shape as a consequence of increasing soluble-poison concentrations. Again, it is questionable whether the unusual position of the central control rod (Fig. 23) significantly affected the distribution of the neutron flux. A comparison with Fig. 22, in which both the reactor power and soluble poison concentration were similar, indicates that the effective core in Fig. 23 has a much larger and more uniform radius. How much of this effect may be due to the subcooling is questionable, but the possibility of power-distribution tailoring in a reactor core by control rod manipulation should be more extensively investigated for future applications.

\section{PROPOSED FUTURE STUDIES IN EBWR OR SIMILAR POWER REACTORS}

The success of the program reported above, in which only cobalt foil material was available, indicates that an extension of the work should include a variety of detector foil materials selected to best characterize the neutron energy encountered in the reactor core. Carver and Morgan (2) selected just such a list of materials (see Table II). They did not have the benefit of cadmium covers, so that use of those materials with and without covers should give a wealth of neutron-energy spectrum information. Such a selection has already been obtained for use in the EBWR after modication for the Plutonium Recycle Experiment.

The possibility of using fissionable isotopes for power-reactor studies is also available by this method and may be explored. These would have particular interest with a plutonium core.

The information gained in this study makes it obvious that a soluble poison is valuable in improving and flattening the neutron-flux distribution and, hence, the power distribution in the reactor core. Future studies by flux-distribution techniques and coupled with burnup analyses after prolonged operation would be necessary to confirm the full value of this control technique.

Power tailoring through judicious use of control rods may give better fuel economy, and this can be explored easily by further application and extension of this study.

Plans are under way to utilize this method in the Plutonium Recycle Experiment (modified EBWR). Computer analysis of the data is definitely indicated for the large number of detector foils that will be used. 


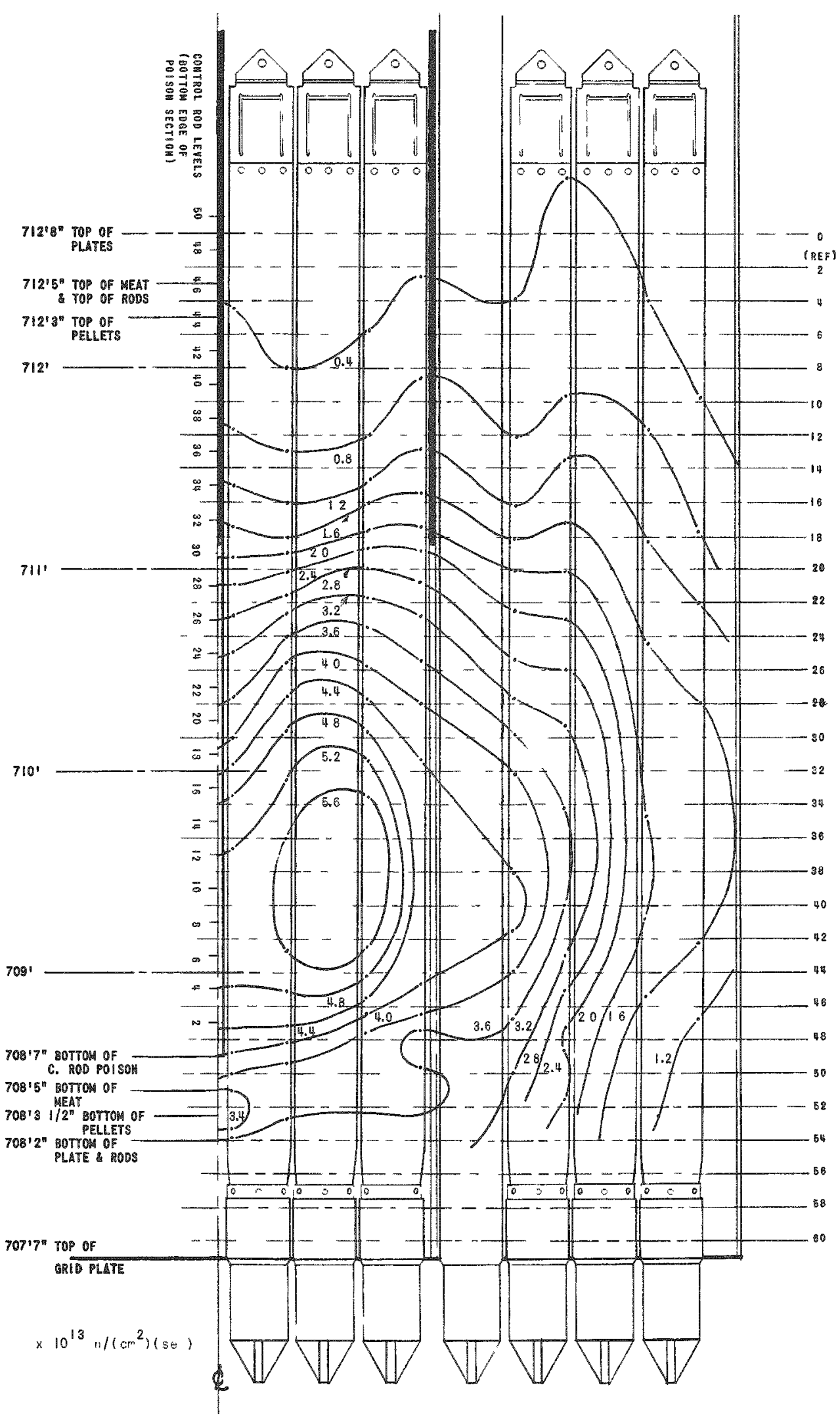

Fig. 18. Neutron-flux Isogram Plot Determined from Bare Cobalt Foil Activation Only, for Reactor Power of $62 \mathrm{MWt}$, Soluble-poison Concentration of 25 ppm as Boric Acid 


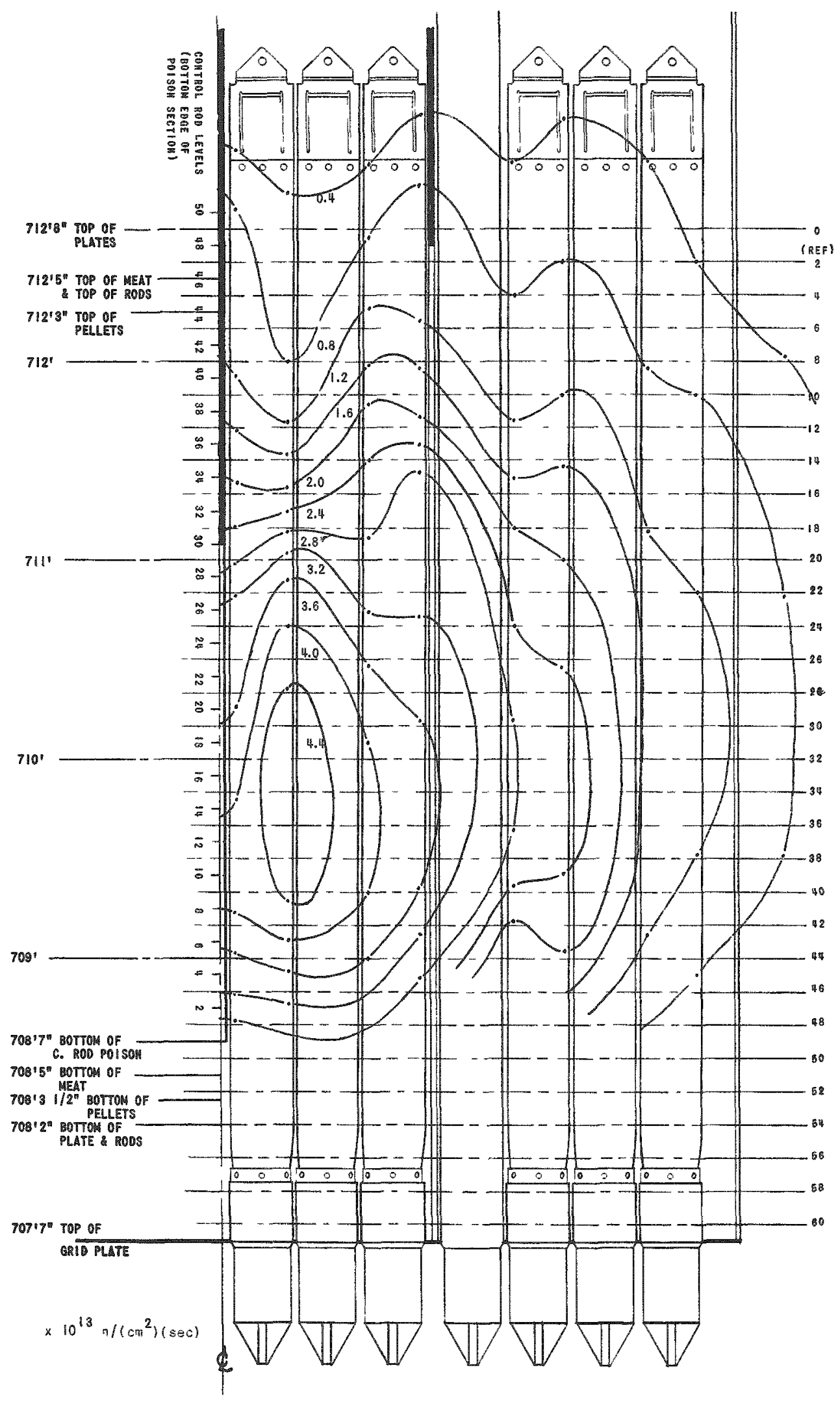

Fig. 19. Neutron-flux Isogram Plot Determined from Bare Cobalt Foil Activation Only, for Reactor Power of $58 \mathrm{MWt}$, Soluble-poison Concentration of 120 ppm as Boric Acid 


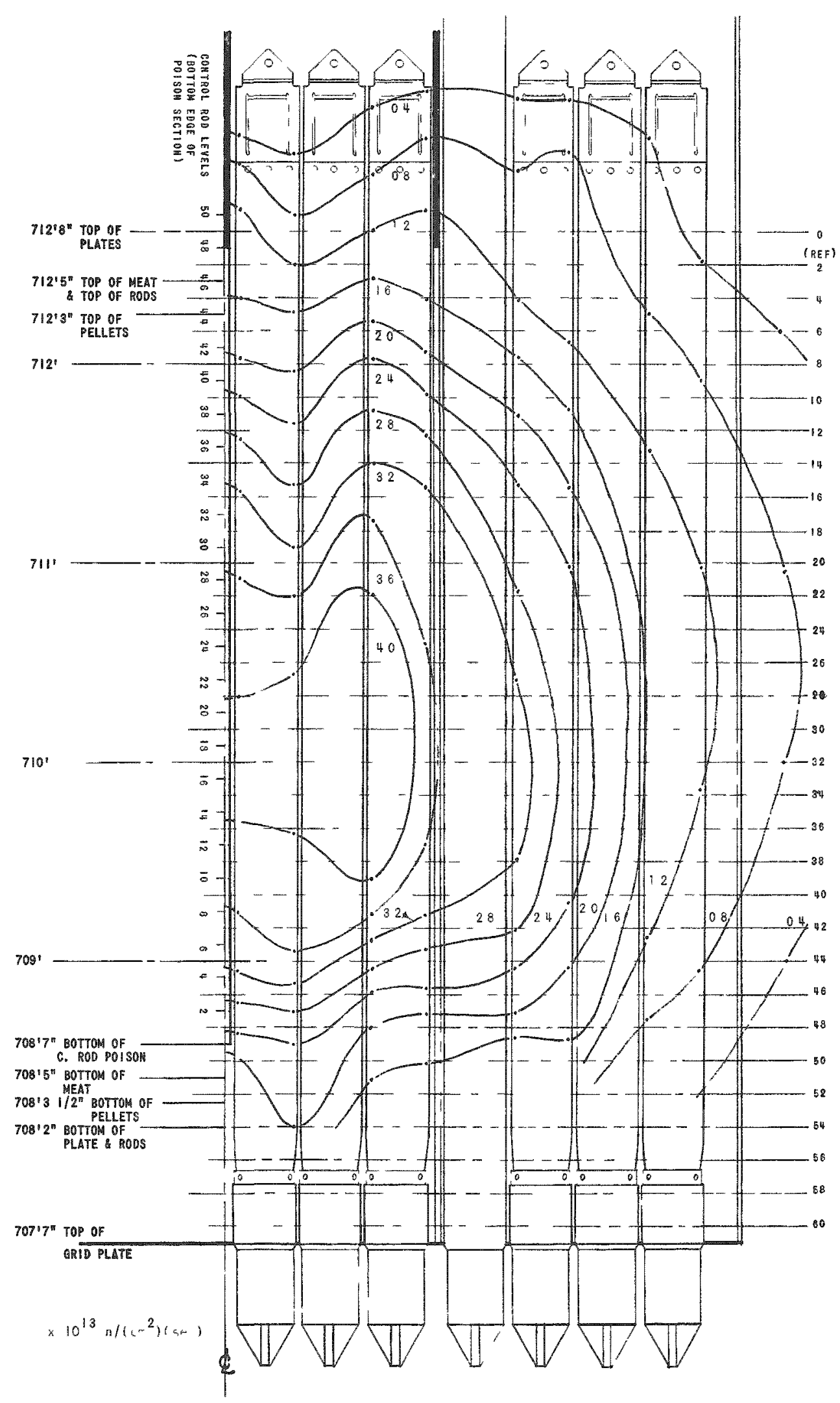

Fig. 20. Neutron-flux Isogram Plot Determined from Bare Cobalt Foil Activation Only, for Reactor Power of $60 \mathrm{MWt}$, Soluble-poison Concentration of 925 ppm as Boxic Acid 


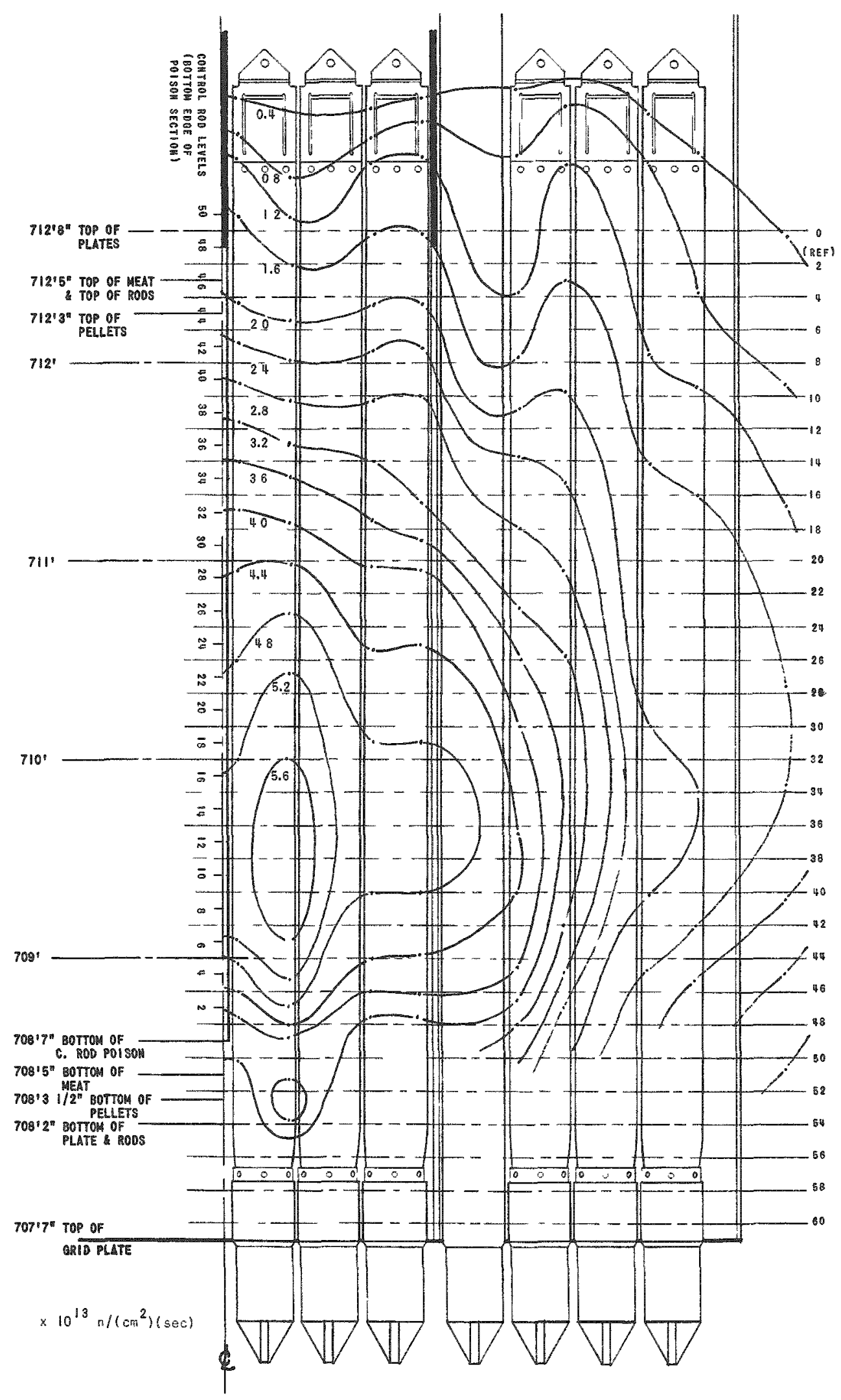

Fig. 21. Neutron-flux Isogram Plot Determined from Bare Cobalt Foil Activation Only, for Reactor Power of 78-80 MWt, Solublepoison Concentration of 25 ppm as Boric Acid 


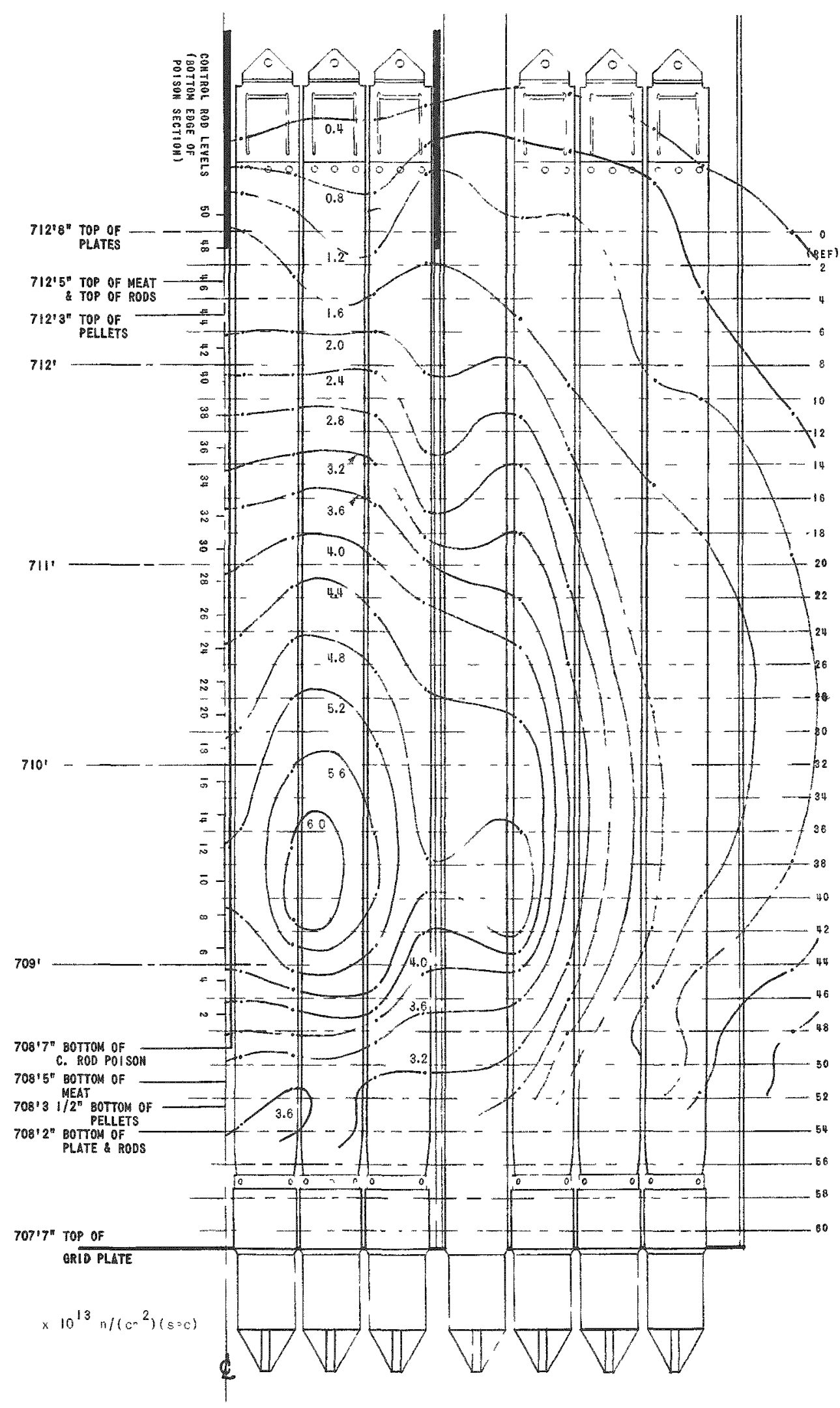

Fig. 22. Neutron-flux Isogram Plot Determined from Bare Cobalt Foil Activation Only, for Reactor Power of $72 \mathrm{MWt}$, Soluble-poison Concentration of 225 ppm as Boric Acid 


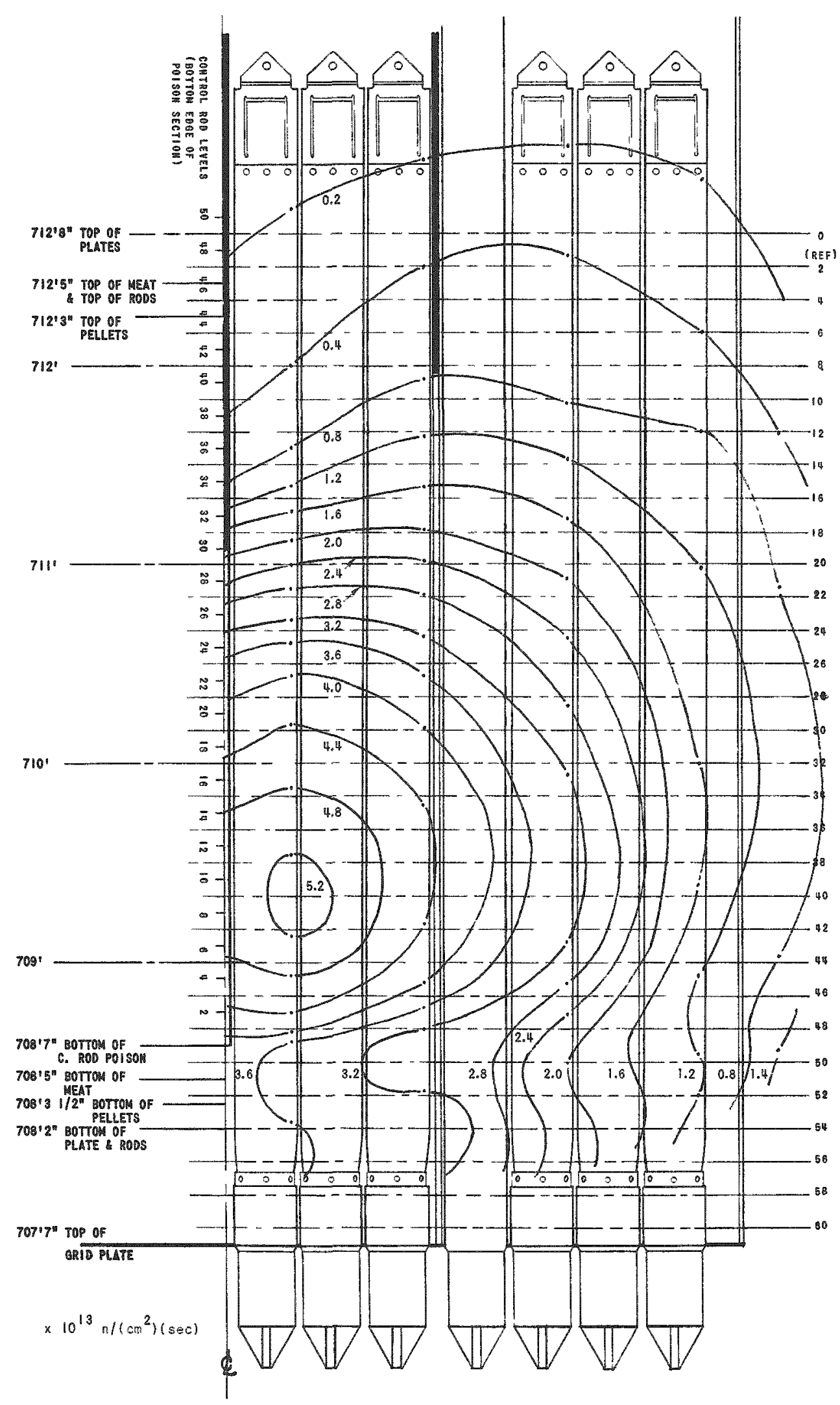

Fig. 23. Neutron-flux Isogram Plot Determined from Bare Cobalt Foil Activation Only, for Reactor Power of $75 \mathrm{MWt}$, Soluble-poison Concentration of $290 \mathrm{ppm}$ as Boric Acid 


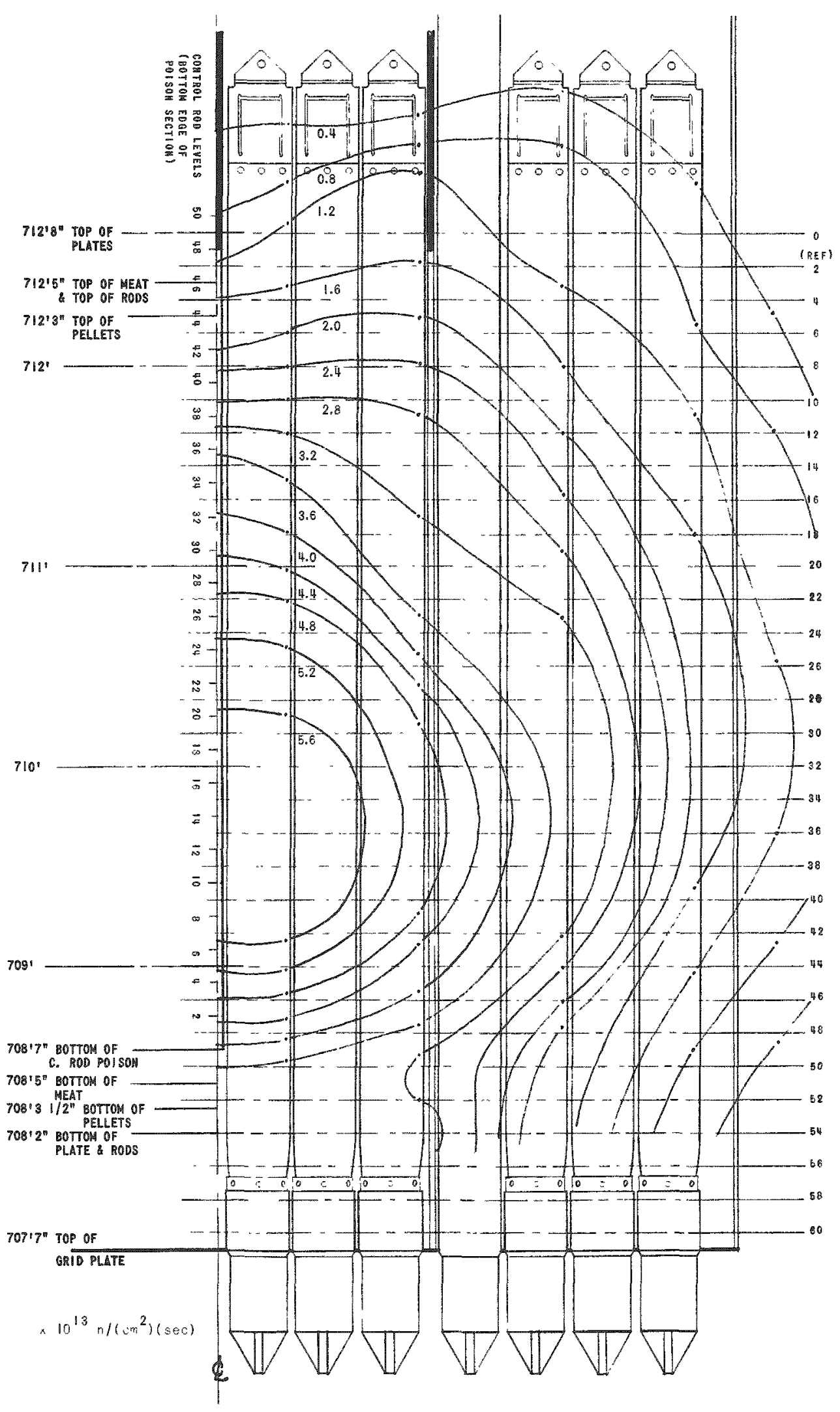

Fig. 24. Neutron-flux Isogram Plot Determined from Bare Cobalt Foil Activation Only, for Reactor Power of $80 \mathrm{MWt}$, Soluble-poison Concentration of 540 ppm as Boric Acid 
Table II

RADIOACTIVANTS TO BE USED IN NEUTRON-FLUX STUDIES IN THE PLUTONIUM RECYCLE EXPERIMENT

\begin{tabular}{|c|c|c|}
\hline Isotope & Resonance Energy & $\begin{array}{c}\text { Natural Element } \\
\text { in Aluminum } \\
(\mathrm{w} / \mathrm{o})\end{array}$ \\
\hline $\begin{array}{l}\operatorname{Lu}^{175} \\
L u^{176}\end{array}$ & $\left.\begin{array}{c}1 / \mathrm{V} \text { Only } \\
0.143\end{array}\right\}$ & $\sim 6 *$ \\
\hline $\mathrm{Eu}^{151}$ & $\left\{\begin{array}{l}0.321 \\
0.461\end{array}\right\}$ & $\sim 0.2 *$ \\
\hline $\begin{array}{l}\operatorname{Ir}^{191} \\
\operatorname{Ir}^{193}\end{array}$ & $\left.\begin{array}{l}0.654 \\
1.303\end{array}\right\}$ & $\sim 0.25 *$ \\
\hline $\operatorname{In}^{115}$ & 1.457 & $0.033 *$ \\
\hline $\mathrm{Au}^{197}$ & 4.906 & $0.056 *$ \\
\hline$W^{186}$ & 18.8 & $\sim 0.065 * *$ \\
\hline $\mathrm{La}^{139}$ & 73.5 & $\sim 0.6 *$ \\
\hline $\mathrm{Co}^{59}$ & 123 & 1.01 \\
\hline $\mathrm{Mn}^{55}$ & 337 & 0.82 \\
\hline $\mathrm{Cu}^{63}$ & 580 & $0.47 *$ \\
\hline
\end{tabular}

* Concentrations similar to those used by Carver and Morgan. (2)

**Suspension in aluminum.*

\section{CONCLUSIONS}

For the first time, detailed neutron-flux distribution information has been obtained from an operating power reactor as a function of a variety of operating parameters. The information was obtained without interfering with normal reactor operation. 
The effects of power changes and soluble-poison concentration have been evaluated, with the obvious conclusion that the neutron-flux distribution and, hence, power distribution in the reactor core are greatly improved in the presence of maximum quantities of soluble poison, i.e., a sufficient quantity to allow nearly complete withdrawal of the control rods.

By reducing neutron leakage from the core through the use of soluble poison, the neutron flux impinging on the reactor vessel (and, it is assumed, the consequent radiation damage) is reduced. Likewise, the peak of the rmal reflux neutrons at the bottom of the core (in the vicinity of the support plate) is also reduced.

One of the most obvious conclusions is that more work is needed to extend the knowledge of operating parameter effects on the core power distribution. Such studies should be under the control of the experimenter (contrary to the present case in which the compressed operation schedule of the reactor facility during the preparation and approach to high-power operation was the controlling factor over all the experimentalists involved in the program) to the extent that additional irradiation locations should be available, and the operating parameters should be adjusted for irradiations to maximize the effect under study while reducing interfering effects.

In spite of the limitations encountered by the present study, much useful information was obtained, justifying the effort expended.

\section{ACKNOWLEDGMENTS}

The author wishes to acknowledge the valuable assistance provided by the following persons: R. J. Armani, for advice and standardization of foils; R. E. Grajek and D. K. Hannaman, for their as sistance throughout the project and particularly in the design and construction of the sample handling equipment; and D. L. Vetter and his associates, for preparation and installation of the irradiation loops in the reactor. The help of the Reactor Engineering Division and Reactor Operations Division EBWR staff in the conduct of the studies is also appreciated. 


\section{REFERENCES}

1. W. G. Knapp, Method for Neutron Flux Studies in an Operating Power Reactor Using Bare and Cadmium-covered Radioactivants, ANL-7011 March 1965.

2. J.G. Carver and W. R. Morgan, Selection of a Set of Radioactivants for Investigating Slow Neutron Spectra, Paper No. ICAA/4, Proc. 1961 Intern. Conf. Mod. Trends Activation Analy. College Station, Texas (1961).

3. T. C. Parkinson and S. Salah, Integral Spectrum Measurements with Lutetium, Trans. Am. Nucl. Soc.4 No.2, 268-69 (1961).

4. J.R. Bell and J. K. Miles, Calibration of Foils for Neutron Flux Measurements. NARF-61-18T (June 1961).

5. R. M. Carroll, Argon Activation Measures Irradiation Flux Continuously, Nucleonics 20 , No.2,42-43(1962).

6. A. J. Kompanek, Jr, and E.C. Tarnuzzer, Neutron-activated Wires Plot Fluxes in Yankee Core, Nucleonics 20, No, 2, 44-46 (1962).

7. The Experimental Boiling Water Reactor, ANL-5607 (May 1957).

8. J. F. Matousek, Modifications of the Experimental Boiling Water Reactor (EBWR) for Higher-power Operation (Supplement to ANL-5607), ANL-6552 (Apri1 1962)。

9. E. A. Wimunc and J. M. Harrer, Hazards Evaluation Report Associated with the Operation of EBWR at $100 \overline{\mathrm{MW}}$, ANL-5781 Addendum (Revision 1), (October 1960).

10. R. Avery et a1. EBWR Core 1A Physics Analysis. ANL-6305 (February 1961).

11. E. A. Wimunc et a1. Performance Characteristics of EBWR from

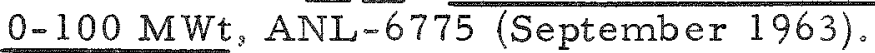

12. D. J.Hughes and R. B. Schwartz, Neutron Cross Sections, BNL-325 (July 1.958).

13. C.H. Westcott, Effective Cross Section Values for Well-moderated Thermal Reactor Spectra. CRRP-960 (November 1960).

14. Reactor Physics Constants. ANL-5800 (August 1958).

15. Reactor Development Program Progress Report. ANL-6307, pp.4-5 (January 1961). 